\title{
Harmattan, Saharan heat low, and West African monsoon circulation: modulations on the Saharan dust outflow towards the North Atlantic
}

\author{
Kerstin Schepanski, Bernd Heinold, and Ina Tegen \\ Leibniz Institute for Tropospheric Research (TROPOS), Leipzig, Germany \\ Correspondence to: Kerstin Schepanski (schepanski@tropos.de)
}

Received: 3 April 2017 - Discussion started: 15 May 2017

Revised: 31 July 2017 - Accepted: 3 August 2017 - Published: 1 September 2017

\begin{abstract}
The outflow of dust from the northern African continent towards the North Atlantic is stimulated by the atmospheric circulation over North Africa, which modulates the spatio-temporal distribution of dust source activation and consequently the entrainment of mineral dust into the boundary layer, as well as the transport of dust out of the source regions. The atmospheric circulation over the North African dust source regions, predominantly the Sahara and the Sahel, is characterized by three major circulation regimes: (1) the harmattan (trade winds), (2) the Saharan heat low (SHL), and (3) the West African monsoon circulation. The strength of the individual regimes controls the Saharan dust outflow by affecting the spatio-temporal distribution of dust emission, transport pathways, and deposition fluxes.

This study aims at investigating the atmospheric circulation pattern over North Africa with regard to its role favouring dust emission and dust export towards the tropical North Atlantic. The focus of the study is on summer 2013 (June to August), during which the SALTRACE (Saharan Aerosol Long-range TRansport and Aerosol-Cloud interaction Experiment) field campaign also took place. It involves satellite observations by the Spinning Enhanced Visible and InfraRed Imager (SEVIRI) flying on board the geostationary Meteosat Second Generation (MSG) satellite, which are analysed and used to infer a data set of active dust sources. The spatio-temporal distribution of dust source activation frequencies (DSAFs) allows for linking the diurnal cycle of dust source activations to dominant meteorological controls on dust emission. In summer, Saharan dust source activations clearly differ from dust source activations over the Sahel regarding the time of day when dust emission begins. The Sahara is dominated by morning dust source
\end{abstract}

activations predominantly driven by the breakdown of the nocturnal low-level jet. In contrast, dust source activations in the Sahel are predominantly activated during the second half of the day, when downdrafts associated with deep moist convection are the major atmospheric driver. Complementary to the satellite-based analysis on dust source activations and implications from their diurnal cycle, simulations on atmosphere and dust life cycle were performed using the mesoscale atmosphere-dust model system COSMOMUSCAT (COSMO: COnsortium for Small-scale MOdelling; MUSCAT: MUltiScale Chemistry Aerosol Transport Model). Fields from this simulation were analysed regarding the variability of the harmattan, the Saharan heat low, and the monsoon circulation as well as their impact on the variability of the Saharan dust outflow towards the North Atlantic. This study illustrates the complexity of the interaction among the three major circulation regimes and their modulation of the North African dust outflow. Enhanced westward dust fluxes frequently appear following a phase characterized by a deep SHL. Ultimately, findings from this study contribute to the quantification of the interannual variability of the atmospheric dust burden.

\section{Introduction}

Mineral soil particles eroded from bare soils by wind and subsequently mixed into the atmosphere contribute significantly to the global atmospheric aerosol burden (Tegen and Schepanski, 2009). Once suspended in the atmosphere, dust aerosol interacts with solar and terrestrial radiation and 
is involved in cloud- and precipitation-forming processes (Carslaw et al., 2010; Tao et al., 2012). Depending on its mineralogical composition, which is determined by the source region, dust transported to remote places may deliver micronutrients and thus fertilize terrestrial and marine ecosystems (Okin et al., 2004; Mahowald et al., 2005). Besides its impact on the environment, dust suspended in the air affects the anthroposphere; dust haze reduces the air quality and is considered to be responsible for increased cases of respiratory diseases, poor human health, and reduced quality of life in general (Morman and Plumlee, 2013).

During the last decades, much effort has been put into research understanding processes involving dust aerosols such as dust radiative feedback, dust cloud interactions, dust (iron) fertilization, and the contribution of dust to reduced air quality and associated concerns on human health, technical devices, or infrastructure. For estimating the impact of dust on the Earth system, knowledge of the atmospheric dust life cycle consisting of dust source activation and subsequent dust emission, dust transport routes, and dust deposition is crucial. Although dust transport pathways are generally well represented by atmosphere-dust models, the knowledge of the spatial distribution of dust sources and their geomorphological characteristics are still limited although vital for a realistic simulation of the full atmospheric dust life cycle (Schepanski et al., 2013). Today, a diversity of atmospheredust model systems are available for the large eddy simulation (LES) scale (e.g. Klose and Shao, 2013), the regional scale (e.g. Heinold et al., 2011; Chaboureau et al., 2016), and the global scale (e.g. Ridley et al., 2014), which together illustrate the range of uncertainty in dust concentration distributions. For North Africa, the dust model intercomparison study carried out in the framework of AeroCom (Huneeus et al., 2011) suggests a range of annual dust emission fluxes of 400 to $2200 \mathrm{Tg}_{\text {year }}{ }^{-1}$.

Recent studies analysing satellite observations provide new insights in the spatio-temporal distribution of active dust sources and thus allow for a detailed analysis of their variability in space and time (Schepanski et al., 2009b; Tegen et al., 2013; Wagner et al., 2016). Thereby, the temporal resolution of the satellite data is crucial - as a temporal offset between dust source activation and satellite overpass may lead to a misplacement of dust sources (Schepanski et al., 2012; Kocha et al., 2013). An as-accurate-as-possible inferred spatial distribution of dust sources allows for examining geomorphological units (Crouvi et al., 2012) and mineralogical characteristics (Formenti et al., 2014) of dust sources. These characteristics ultimately determine the nature of the dust source in terms of sediment supply and susceptibility to interannual variability, the contribution to the dust burden in remote locations (Banks et al., 2017), and the optical and microphysical properties of eroded dust aerosols (Carslaw et al., 2010). A map of dust source activations including the time indicating the onset of dust emission as published by Schepanski et al. (2007) further allows investiga- tion of the meteorological controls on dust emission and to quantify the role of frequently recurring synoptic-scale atmospheric features for frequently active dust sources. From such studies, the nocturnal low-level jet (LLJ) was found to be the dominant driver for dust source activation over North Africa (Schepanski et al., 2009b), which was verified by several follow-up studies (e.g. Fiedler et al., 2013, 2014; Tegen et al., 2013). Besides the LLJ, deep moist convection embedded in the intertropical discontinuity region fosters the formation of dust fronts by cold pools in particular over the Sahel zone during the wet season (Bou Karam et al., 2009; Heinold et al., 2013; Fiedler et al., 2014). The advection of cooler air from the Mediterranean Sea into the Sahara, occasionally reaching the Sahel zone, may promote the formation of a Soudano-Saharan depression. This depression then migrates westwards, eventually turns anticyclonically into a northward direction and may be enhanced by Atlas lee cyclogenesis ultimately forming a Mediterranean cyclone (Schepanski and Knippertz, 2011).

Various measurement campaigns and modelling efforts have been carried out investigating the atmospheric dust cycle and related processes in order to improve the general understanding of dust suspended in the atmosphere and related atmospheric processes. With focus on Saharan dust and related dust radiation feedbacks and cloud formation processes, several projects focused on the northern African continent and its adjacent dust outflow regions during the last decade: the SAMUM-1 experiment (Saharan Mineral Dust Experiment, Heintzenberg, 2009), which was conducted in Southern Morocco during May and June 2006 and aimed at characterizing Saharan dust particles to quantify dustrelated radiative effects; the SAMUM-2 experiment (Ansmann, 2011), which took place during January and February 2008 at Cabo Verde in the so-called dust outflow region, and focused on the optical properties of aged dust and dust aerosol mixed with biomass-burning aerosol; the DODO (Dust Outflow and Deposition to the Ocean, McConnell et al., 2008) experiments aiming at determining dust radiative properties over the dust outflow region in 2006; the Fennec project (Ryder et al., 2015) aiming at improving the understanding of physical processes that control the Saharan climate system and conducting field experiments during June and July 2011 and 2012; and the SALTRACE experiment, which was conducted in June to July 2013 and investigated the dust properties related to dust radiative effects and microphysical processes of aged Saharan dust that has been transported to the Caribbean (Weinzierl et al., 2017). Although many studies focus on the continental region including the adjacent dust outflow, measurements during SALTRACE were obtained at both sides of the tropical Atlantic: at Cabo Verde, relatively close to the northern African continent, and at Barbados, situated in the Caribbean Sea.

This study focuses on North African dust source activations and their influence on atmospheric circulation patterns that ultimately determine dust transport towards the 
Caribbean Sea. It was carried out in the framework of the SALTRACE project and contributes to the understanding on the origin of dust aerosol transported to and eventually measured in the Caribbean (Weinzierl et al., 2017). The aim of this study is twofold. First, it discusses the spatio-temporal distribution of active dust sources over North Africa regarding implicit information on the meteorological elements driving dust emission and their predominance during a typical summer season. To achieve this, the study makes use of satellite observations for identification of active dust source regions. Second, the study elaborates the atmospheric circulation with regard to its relevance for dust source activation and dust transport towards the tropical North Atlantic. For this, simulations from the dust-atmosphere model system COSMO-MUSCAT are analysed. The period of investigation is chosen to cover the entire summer season June to August 2013. Transport-related processes occurring during dust transport over the North Atlantic are presented in a companion paper by Heinold et al. (2017).

The paper is structured as follows. Following a general introduction to atmospheric controls on dust source activation in Sect. 2, an overview of the data sets used for the identification of dust sources and characterization of connected atmospheric circulation patterns is given in Sect. 3. Section 4 presents the spatio-temporal variability in dust source activation and leads to the analysis of different atmospheric features modulating the North African dust burden in Sect. 6. Aspects addressed therein are discussed in Sect. 7 with regard to its impact on dust export fluxes, and summarized in Sect. 8.

\section{Atmospheric controls on dust source activation}

\subsection{Dust source characteristics}

Dust emission is a threshold problem: momentum provided by the wind is an essential prerequisite to mobilize soil particle from bare ground. Thereby, the minimum amount of momentum required for particle mobilization depends on surface characteristics such as soil texture and particle size distribution (Kok et al., 2012). However, dust mobilization may also be limited by the soil erodibility describing the susceptibility of the surface for wind erosion. The soil erodibility is determined by (1) roughness elements such as vegetation, rocks, or soil clods; (2) intrinsic characteristics such as soil texture, mineralogy, or soil content of organic matter; and (3) temporally varying characteristics such as soil moisture, soil aggregation, crusting, and the availability of erodible material (Webb and Strong, 2011). All characteristics in concert determine the interparticle cohesive forces and thus the amount of momentum required for particle mobilization. Consequently, wind speed distribution and surface sediment characteristics together determine the dust emission flux. On a daily basis, in particular the supply of momentum and thus the wind speed distribution is the dominant factor controlling dust source activation and subsequent dust emission, ultimately resulting into its diurnal cycle (Schepanski et al., 2009b). Additionally, precipitation and subsequent increase in soil moisture control dust emission in particular in the Sahel zone and the northern margins of the Sahara, where convective precipitation associated with mesoscale convective systems (MCSs) and cyclogenesis respectively occurs (Fiedler et al., 2014; Bergametti et al., 2016). Vegetation cover and its changes contribute significantly to the dust variability, in particular at seasonal timescales in regions with distinct vegetation periods.

The focus of this study is on the atmospheric controls on dust source activation and subsequent dust emission. It discusses different synoptic-scale features of the atmospheric circulation affecting the local wind speed distribution and thus inhibiting or forcing dust source activation, which ultimately result in a local variability in the occurrence frequency of dust source activation and consequently atmospheric dust concentrations downwind.

\subsection{Atmospheric circulation over North African dust source areas}

Besides the availability of sediments susceptible to wind erosion, the presence of sufficiently high wind speeds is the most limiting factor for dust emission. Although local wind speeds determine local dust mobilization and subsequent entrainment into the atmospheric boundary layer, the atmospheric circulation provides the general conditions for the state of the atmosphere at local scale. For example, atmospheric turbulence, static stability, wind speed distribution, and gustiness are affected by pressure gradients determining the prevailing geostrophic wind, and advection of humidity and temperature.

The atmospheric circulation over North Africa in boreal summer (June, July, August: JJA) is dominated by three major features: (1) the harmattan wind, (2) the Saharan heat low (SHL), and (3) the West African monsoon (WAM) circulation including the African easterly waves (AEWs), which are characterized by distinct troughs and ridges. The harmattan is the name for the northeasterly trade winds over North Africa that result from the continental-scale pressure gradient between the subtropical subsidence zone and the Intertropical Convergence Zone (ITCZ). With regard to dust entrainment, these winds are of particular interest as they are involved in the development of the nocturnal LLJs, which are the dominant and frequent drivers for dust source activation over North Africa (Schepanski et al., 2009a, b; Fiedler et al., 2013; Schepanski et al., 2015a). As part of the WAM, cool and moist air is transported northward from the Gulf of Guinea into the northern African continent. The resulting baroclinicity fosters the generation of nocturnal LLJ embedded in the monsoonal flow at the southern margins of the SHL (Parker et al., 2005a; Bou Karam et al., 2008; Schepanski et al., 
2009a; Fiedler et al., 2013). The atmospheric environment of moist monsoonal air further allows deep moist convection and the development of mesoscale convective systems (MCSs), in particular along the AEJ, which forms a wave structure over the Sahel zone in summer. The SHL plays an important role for the strength of the monsoon trough (Thorncroft and Blackburn, 1999). Dust emission related to deep-moist convection also occurs along the Saharan side of the Atlas mountains, where orographically induced cold pools or lee cyclogenesis result in the generation of dust fronts (Knippertz et al., 2009; Reinfried et al., 2009; Schepanski et al., 2009b; Schepanski and Knippertz, 2011; Bou Karam et al., 2010).

\subsection{The SHL as connecting element in between the harmattan and monsoon circulation}

The SHL is a thermal low formed by intense solar heating of the desert land surface. The heated land surface re-emits thermal energy into the lower atmosphere which subsequent leads to heated air layers. The heated air ascends due to its buoyancy and a zone of low pressure forms at near-surface levels. As the SHL is a heat low, there are no fronts associated. As proposed by Lavaysse et al. (2009), the low-level atmospheric thickness (LLAT) can be applied as a measure to identify the geographical position, the extent, and strength of the SHL. Thereby, the LLAT is related to the mean temperature of the atmospheric layer confined by the 700 and $925 \mathrm{hPa}$ and thus represents the heat-induced dilatation of the lower atmospheric levels.

The SHL is suggested to act as a key element of the atmospheric circulation over North Africa. During summer, it is situated over West Africa between the Atlas Mountains to the north and the Hoggar Massif to the east (Lavaysse et al., 2009). Due to its geographical position, its cyclonic circulation affects the strength of the harmattan winds and the monsoon flow: along its eastern flank the southwesterly monsoon flow is increased, along its western flank the northeasterly harmattan winds are increased (Lavaysse et al., 2009; Parker et al., 2005b). The SHL may even affect the position of the AEJ, as the temperature gradient between the hot and dry Sahara and the cold and moist Gulf of Guinea impacts on the state of the AEJ. The SHL may even interact with the development of AEWs and the position of the monsoon front (Thorncroft and Blackburn, 1999; Chauvin et al., 2010; Lavaysse et al., 2010). The SHL also determines the ventilation of the northern African continent through cooler, maritime air masses that are advected to the Sahara due to increased pressure gradients. On its eastern flank, cooler air masses originating from the Mediterranean Sea are transported into the northern African continent eventually contributing to the atmospheric moisture budget over the Sahel (Vizy and Cook, 2009). On its western flank, air masses originating from the Atlantic ventilate the continent driven by the pressure gradient between the subtropical high (Azores high) and the SHL (Grams et al., 2010). Furthermore, Roehrig et al. (2011) found a modulation of the structure of the Azores high by the so-called pulsation of the SHL. The pulsation of the SHL characterizes the migration of the centre of the SHL from a so-called eastern phase to a so-called western phase (Chauvin et al., 2010; Roehrig et al., 2011). The western phase is associated with higher surface temperatures over the coastal region of Morocco and Mauritania, and a general southwestward propagation of this temperature signature. Lower surface temperatures are evident over the region between Sicily and Libya; this signature is propagating in southeasterly direction. The eastern phase is associated with the opposite temperature signature. As outlined above, the position (eastern phase versus western phase; Chauvin et al., 2010), the depth and extent of the SHL generally interacts and affects the large-scale circulation over North Africa. In particular, the harmattan and monsoon flow modulates the nature of the SHL and vice versa (Lavaysse et al., 2009). Although dust source activation and subsequent dust emission is driven by local wind speed conditions, large-scale circulation determines the local atmospheric conditions fostering or inhibiting dust emission. Modulated by and interacting with harmattan and monsoon circulation, the SHL is an atmospheric element that, on the one hand, can be characterized by its depth and extent and, on the other hand, implicitly reflects both the harmattan and the monsoon. In this study, we use the method proposed by Lavaysse et al. (2009) to identify the position, extent and depth of the SHL from COSMO-MUSCAT geopotential and temperature fields at 700 and $925 \mathrm{hPa}$ level. The area of the SHL is refined to the 90th percentile of the LLAT values.

\subsection{Dust export towards the North Atlantic}

Dust transport towards the tropical Atlantic and across to the Caribbean Sea is determined by the dust conditions over West Africa, the atmospheric circulation advecting the dusty air mass to the coastal regions off West Africa, the entering of the Atlantic region and the formation of the so-called Saharan air layer (SAL) across the Atlantic ocean (e.g. Schepanski et al., 2009a). Although dust emission is the vital element of the dust's journey across the Atlantic, the release of dust-loaded air from the northern African continent to the tropical Atlantic is not inevitable. Dust may also be deposited over the northern African continent. Airborne dust circulating over West Africa may become sucked into the SHL as described by Ashpole and Washington (2013) or form the ridge of an AEW (Jones et al., 2003). In both cases, dust may eventually be pushed towards the Atlantic and released as a dust plume once the SHL is in its western phase (Chauvin et al., 2010) or an AEW enters the Atlantic (Jones et al., 2003). Besides that, dust-loaded air masses are transported towards the Atlantic by the harmattan flow. In that case, the dust export flux is rather continuous compared to the plumelike structure of dust export associated with the intermittent 
nature of the SHL pulsation or the passage of AEWs. In summary, SHL and AEW can be understood as a modulation on the North African dust export within the SAL.

\section{Data sets providing information on the atmospheric dust life cycle}

To elaborate various concepts of controlling mechanism on the atmospheric dust life cycle, in particular dust emission and transport over the northern African continent, this study combines two different data sets: (1) the DSAF (dust source activation frequency) data set providing information on the spatio-temporal distribution of active dust sources inferred from satellite observations, and (2) fields from numerical simulations of the atmospheric dust life cycle using the atmosphere-dust model system COSMO-MUSCAT.

\subsection{Dust source identification}

Satellite observations as these obtained from the geostationary MSG (Meteosat Second Generation) SEVIRI (SpinningEnhanced Visible and Infra-Red Imager) instrument at $15 \mathrm{~min}$ temporal resolution provide convenient data for identifying active dust source. As described by Schepanski et al. (2007), the infrared dust index, which is a red-greenblue (RGB) composite image of different combinations of the brightness temperature of the three SEVIRI channels centred at $8.7,10.8$, and $12.0 \mu \mathrm{m}$ wavelengths, is used to identify active dust source in terms of dust entrainment into the atmospheric boundary layer. Active dust sources are recorded on a $1^{\circ} \times 1^{\circ}$ grid covering North Africa north of $10^{\circ} \mathrm{N}$ building up the DSAF data set.

The dust index provides qualitative information on the presence of airborne dust and has previously been used to locate active dust source within the viewing field of SEVIRI over North Africa (Schepanski et al., 2007, 2009b, 2012) and southern Africa (Vickery et al., 2013). Based on measurements at infrared wavelength, the index is sensitive to atmospheric humidity, which affects the identification of dust layer in regions with high atmospheric humidity such as cold pool outflows (Brindley et al., 2012). However, due to the visual identification of dust plumes the impact of this caveat is minimized compared to automatic retrieval algorithm. The sensitivity against colour shades and propagating plumes is much higher and provides reliable identification. As for most satellite-based observations, no information on the presence of dust is available underneath clouds. Consequently, dust uplift in the vicinity of deep moist convection may remain unrecorded and may result into an underestimation of dust source activations driven by deep moist convection.

Besides the geographical location of active dust sources, the time of day when the dust source became active was recorded and binned at hourly resolution. In the case of several dust source activations per $1^{\circ} \times 1^{\circ}$ grid cell, the earli- est one determined the recorded time. A comparison of dust source data sets based on 15 min resolution satellite observation and daily observations has pointed towards a shift in dust source regions identified in downwind direction due to the temporal offset between onset of dust source activation and satellite overpass (Schepanski et al., 2012).

\subsection{COSMO-MUSCAT dust simulations}

Fields describing the state of the atmosphere and the dust aerosol distribution are taken from the mesoscale atmosphere-dust model system COSMO-MUSCAT (COSMO: COnsortium for Small-scale MOdelling; MUSCAT: MUltiScale Chemistry Aerosol Transport Model), which is a non-hydrostatic atmosphere model (COSMO version 5.0) that is coupled online to the 3-D chemistry tracer transport model MUSCAT. Schemes on dust emission (Tegen et al., 2002) and deposition (Berge, 1997; Jakobson et al., 1997; Zhang et al., 2001) are implemented in MUSCAT and online driven by atmospheric and hydrological fields calculated by COSMO (Heinold et al., 2011). Thus, the full atmospheric dust cycle consisting of dust mobilization and emission, transport, and dry/wet deposition is represented by the COSMO-MUSCAT simulations. Five size bins ranging from 0.1 to $48 \mu \mathrm{m}$ are defined to resolve the size dependency of dust transport and deposition. Depending of the state of the atmosphere, in particular the near-surface wind distribution, dust emission fluxes are calculated for regions identified as active dust source using the dust source activation frequency (DSAF) mask inferred from MSG SEVIRI observations as described by Schepanski et al. (2007). By applying this DSAF mask, all grid cells where dust source activation was observed at least twice within the time period 2006-2012 were treated as potential dust sources. The dust flux then is calculated using the actual wind fields and atmospheric/hydrological conditions calculated by COSMO and considering soil texture and soil size distribution as proposed by Tegen et al. (2002). Additionally, the aerodynamic roughness length $z_{0}$ is implemented for adjusting the dust emission scheme to the near-surface wind speed distribution provided by COSMO. For grid cells where the maximum monthly average of the leaf area index (LAI) is less than 0.1 and the standard deviation of the sub-grid-scale orography is larger than $50 \mathrm{~m}$, the roughness length from Prigent et al. (2012) is taken; elsewhere $z_{0}$ is set to the optimum value of $z_{0}=0.001 \mathrm{~cm}$ to more accurately represent dust emission from sources located within the mountain foothills and the Sahel. This model setup has already been successfully applied and validated against several observation data sets as described in Schepanski et al. (2009a), Schepanski et al. (2015b, 2016), Heinold et al. (2011), and Tegen et al. (2013).

COSMO-MUSCAT simulations are performed for the period 15 May to 31 August 2013. The simulation period is chosen to start mid-May to allow for a realistic atmospheric dust distribution for the period of interest (June- 


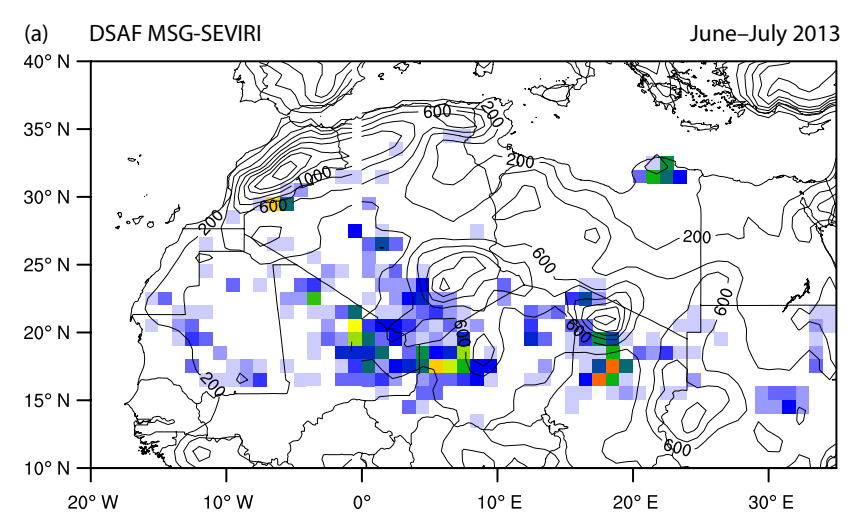

(b) DSAF MSG-SEVIRI June-July 2006-2009
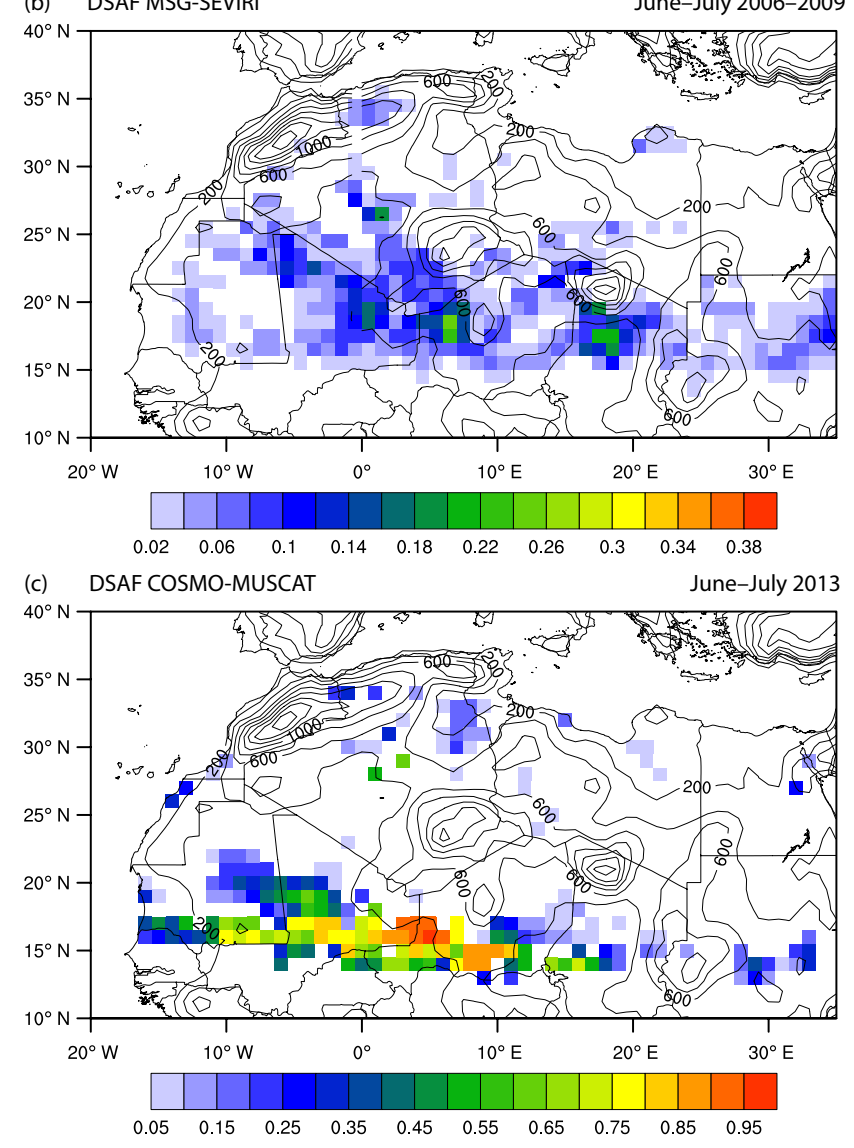

Figure 1. Occurrence frequency of dust source activation (fraction of days with dust occurrence) for the 2-month period June and July for 2013 (a) and the 4-year period 2006-2009 (b). (c) Occurrence frequency of dust source activation (DSAF) obtained from COSMO-MUSCAT simulations. For each day, grid cells representing dust emission fluxes exceeding $1 \times 10^{-4} \mathrm{~kg} \mathrm{~m}^{2} \mathrm{day}^{-1}$ were counted as dust emission event. Topography $(\mathrm{m})$ is given by the black solid lines at $200 \mathrm{~m}$ intervals.

August 2013). The model domain is chosen to capture dust source region contributions to the dust export from North Africa towards the Caribbean and its transport pathways. Thus, COSMO-MUSCAT simulations at $28 \mathrm{~km}$ horizontal grid spacing and 40 vertical $\sigma-p$ levels are performed for the domain spanning between $10.0^{\circ} \mathrm{S}, 70.0^{\circ} \mathrm{W}$ and $40.5^{\circ} \mathrm{N}$, $38.8^{\circ} \mathrm{E}$. The domain covers West Africa including the parts of the Sahara relevant for westward dust export, and the tropical North Atlantic as far as the Caribbean. The lowest level is centred at $10 \mathrm{~m}$ above ground.

\section{North African dust source activity during June and July 2013}

Active dust sources were inferred from MSG SEVIRI IR dust index images for the time period 1 June to 31 July 2013 as outlined in Sect. 3. The 2-month period covers the SALTRACE field campaign, which took place from 10 June to 14 July 2013. Whereas the dust measurements obtained over Barbados characterize the last part of the atmospheric dust cycle and thus the final stage of the life cycle of dust in the atmosphere, an encompassing analysis includes the discussion of dust sources and dust emission processes. For example, Groß et al. (2015) identified different phases of atmospheric dustiness over the Caribbean and Barbados, which were characterized by differing optical properties and atmospheric aerosol layer structures. These phases were related to active dust source regions in order to investigate the relation between dust source characteristics, dust transport route, and arrival over the Caribbean.

The combination of time and place of dust source activation thus states that all conditions for dust emission were fulfilled. Here we focus on locally occurring wind speeds that are sufficiently high to foster dust entrainment. The diurnal wind speed distribution is determined by the large-scale atmospheric circulation modulated by smaller-scale processes such as regional wind regimes and local boundary layer processes. Prominent examples for large-scale features are the harmattan or WAM circulation; regional wind regimes are, for example, the mountain and valley breeze, as well as the formation of LLJs. As topography and atmospheric circulation, which determine the local wind speed distribution and thus the frequency of fulfilling the major atmospheric precondition for dust emission, are not equally distributed over North Africa, spatial and temporal variabilities in dust source activation are expected.

The analysis of the spatial distribution of frequently active dust sources as shown in Fig. 1a illustrates that frequently active dust sources that also dominate the June-July 2013 period are located within the mountain regions over North Africa besides the dust sources located in the Bodélé Depression. In particular, dust source embedded in the mountain foothills of the Hoggar-Adrar-Air Massif become frequently active during this period. Dust sources with pronounced activity are also observed over the Al Jabel Akhadra Massif in Libya and the southern fringe of the Atlas Mountains. Also, dust sources over southern Mauritania are found to be active. The predominance of dust sources embedded in moun- 


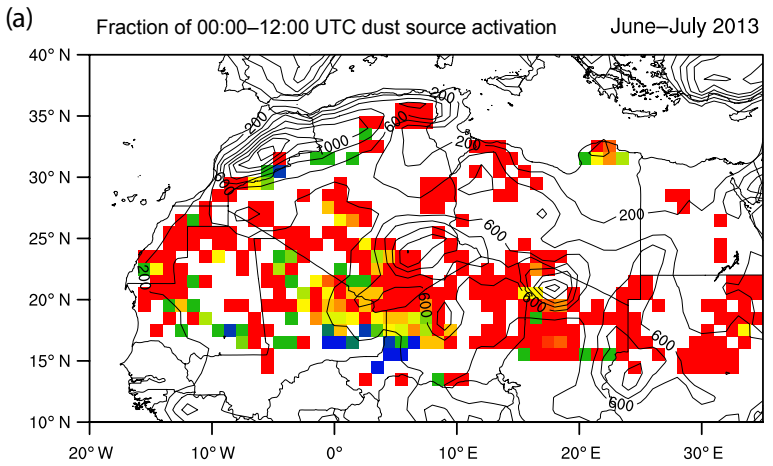

(b) Dust source activation frequency (DSAF) June-July 2013, 00:00-12:00 UTC

(c) Fraction of 12:00-00:00 UTC dust source activation June-July 2013
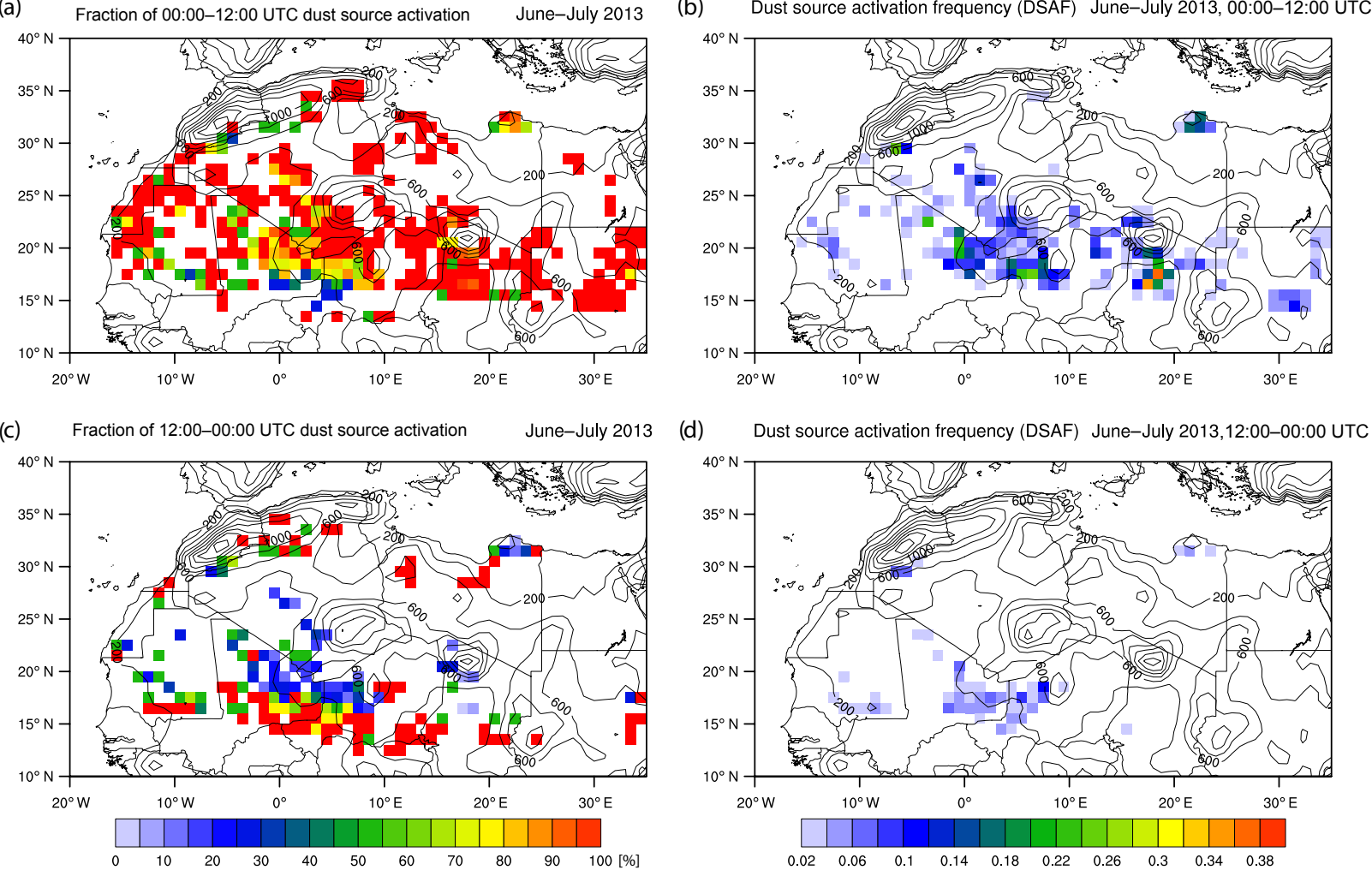

(d) Dust source activation frequency (DSAF) June-July 2013,12:00-00:00 UTC

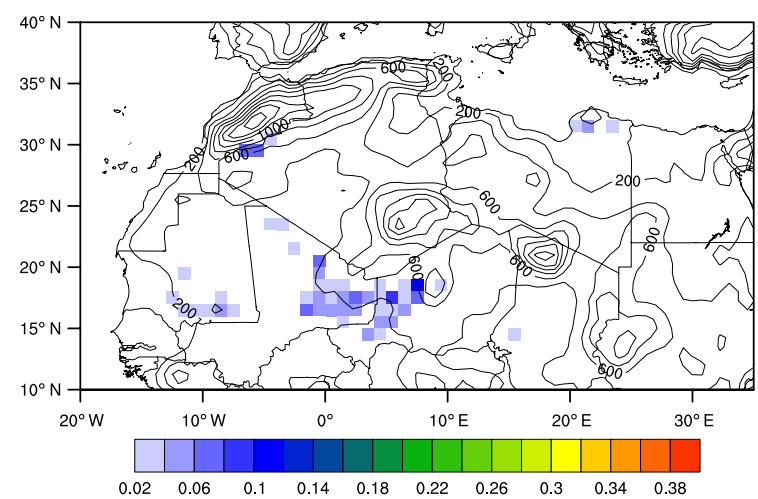

Figure 2. Occurrence frequency of dust source activation (fraction of days with dust occurrence) for the 2-month period June and July 2013 for the first half of the day $(\mathbf{a}, \mathbf{b})$ and the second half of the day $(\mathbf{c}, \mathbf{d})$ expressed by fraction of the total (a, c) and occurrence frequency (b, d).

tain regions agrees with earlier findings based on the DSAF database (i.e. Schepanski et al., 2009b, 2012).

Comparing the June-July 2013 period to the 4-year JuneJuly 2006-2009 period (Fig. 1b), the patterns of the spatial distribution of DSAF are matching. However, from a broader perspective, the level of occurrence frequency is generally higher for the 2006-2009 period than for 2013, but the maximum is higher for 2013. This can be explained by the overall high DSAF during 2007-2008 as discussed by Tegen et al. (2013) and Wagner et al. (2016). Also, the Bodélé Depression is significantly more active during 2013 than compared to the 2006-2009 mean.

The temporal distribution of dust source activation, in particular its diurnal cycle, provides implicitly information on the meteorological driver fostering dust source activation and subsequent dust entrainment into the atmosphere (Schepanski et al., 2009b). Dust source activations during the first half of the day are predominantly linked to the breakdown of the nocturnal LLJ, whereas dust source activations occurring during the second half of the day are predominantly related to (moist) convection (Schepanski et al., 2009b). The climatology of the occurrence frequency of the LLJ shows in particular high frequencies where the harmattan is the dominating wind regime, and over regions of maritime air inflow such as the Atlantic and Mediterranean ventilation areas, and along the northern front of the WAM (see Schepanski et al., 2009b; Fiedler et al., 2013). Moist convection and related MCSs develop more frequently towards the south, where the arid Sahara transitions into the semi-arid Sahel zone. With northward propagation of the monsoon front, MCSs frequently migrate into the desert, where downdrafts generate dust storms, which are frequently associated with the formation of impressive dust fronts - the so-called haboobs.

Figure 2 presents the dust source activation frequency for North Africa and thus enables us to identify major dust source regions. The figure shows the DSAFs separately for the two halves of the day: Fig. $2 \mathrm{a}$ and $\mathrm{b}$ present only those beginning their emission during the first half of the day. Figure 2a depicts the fraction part of all dust source activations, whereas Fig. 2b illustrates the occurrence frequency. Both plots together show first the absolute relevance of individual dust source regions, and second the relative importance depending on the time. DSAFs for the second half of the day are shown similarly in Fig. 2c and d. Generally, dust emission over North Africa predominantly onsets during the first half of the day, except for some dust source regions in the Sahel zone. A north-south gradient with regard to the time of the day of dust source activation is evident. Dust source regions 
(a) Fraction of 00:00-12:00 UTC dust source activation June-July 2006-2009 (b)

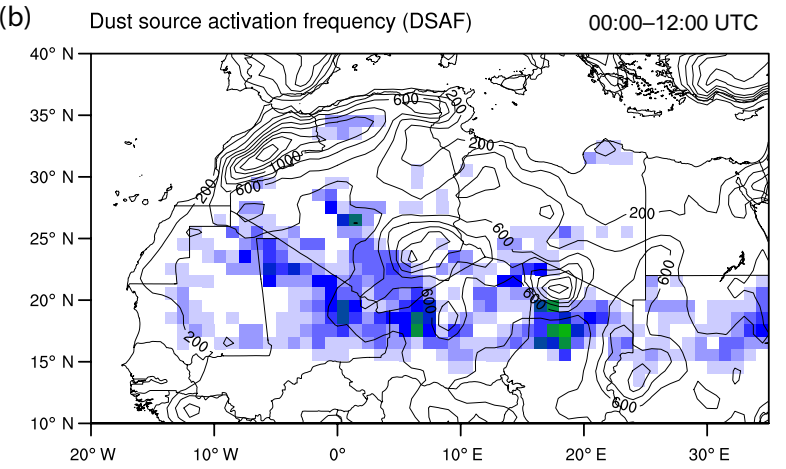

(c) Fraction of 00:00-12:00 UTC dust source activation June-July 2006-2009
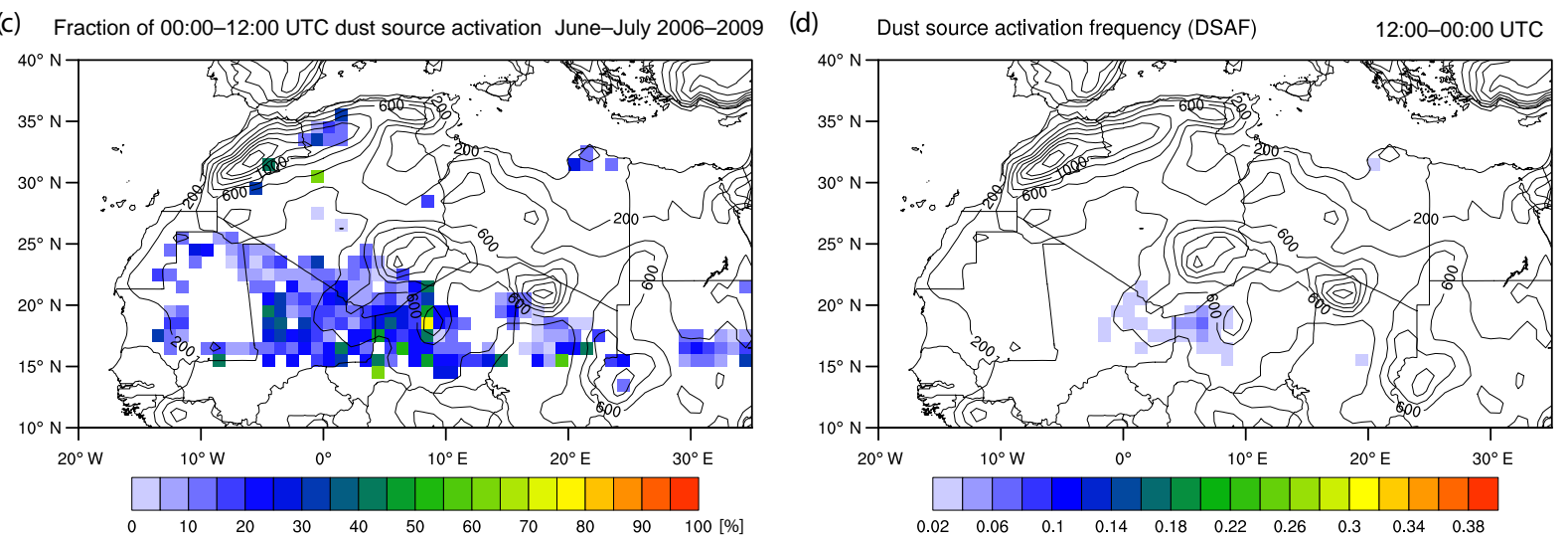

Figure 3. Same as Fig. 2 but for June-July 2006 to 2009.

activated during the 00:00-12:00 UTC time slot dominate, both in relative and absolute frequencies. The second half of the day (12:00-00:00 UTC) is dominated by dust source activations in particular over the Sahel and the Mediterranean coastal region (northern tip of Libya) to the north of the Sahara. One prominent area representing this influence of the northward propagation of the monsoon front is the region southwest of the Hoggar-Adrar-Air mountain region. That region is characterized by enhanced absolute occurrence frequencies during the 12:00-00:00 UTC time slot.

Although smoother due to more data and the interannual variability as documented by Schepanski et al. (2012), Tegen et al. (2013), and Wagner et al. (2016), a similar distribution is evident from the four-year period 2006-2009 as shown in Fig. 3 for the months June and July. Figure $3 a$ and $b$ illustrate the DSAFs observed during the first half of the day (00:0012:00 UTC), and Fig. $3 \mathrm{c}$ and $\mathrm{d}$ for the second half of the day (12:00-00:00 UTC). Panels (a) and (c) show the fraction of all dust source activations, and panels (b) and (d) depict the occurrence frequency illustrating the absolute and the relative relevance of individual dust source regions with regard to the time of day. As for June-July 2013, regions affected by the propagation of the monsoon front show an enhanced contribution of dust source activations during 12:00-00:00 UTC (see Fig. 3a, c). Nevertheless, dust source activations occur- ring during the 00:00-12:00 UTC period dominate the allday DSAF as shown in Fig. $1 b$.

\section{Atmospheric dust distribution: Validation of dust source activation and aerosol optical depth}

The atmospheric dust load is often used to assess the different elements of the atmospheric dust life cycle consisting of (1) dust emission, (2) dust transport, and (3) dust deposition. Dust emission is determined by source characteristics (i.e. sediment supply and availability) and wind strength, and thus dust emission fluxes are representative of the connection of these factors. Dust transport results from prevailing wind regimes, but also particle buoyancy, which is influenced by atmospheric stability respective turbulence. By validating dust loading provided by numerical simulations against in situ measurements, the model's ability on balancing out dust emission flux, transport capacity of the atmosphere, and deposition flux is verified. Dust deposition summarizes all dust removal processes. The model's ability to correctly represent local deposition fluxes implies the correct representation of dust emission and transport. As local in situ measurements of dust emission and deposition fluxes require an extensive measurement infrastructure, measurements of the atmospheric dust load appear a realistic compromise. As the atmospheric dust load is modulated by both the dust emis- 
sion and deposition fluxes, this parameter is assumed to be representative for the entire atmospheric dust life cycle.

Although in situ measurements of dust emission fluxes at continental scale are challenging, DSAFs inferred from satellite data such as the DSAF data set (Schepanski et al., 2007, 2012) allow for qualitative validation of dust source activity. Figure 1c illustrates the DSAF calculated from COSMOMUSCAT dust emission fluxes for June-July 2013. In order to obtain results comparable with the DSAF data, the COSMO-MUSCAT emission fluxes were interpolated onto a $1^{\circ} \times 1^{\circ}$ grid. To account for the fact that the MSG IR dust index will not allow for identification of very weak dust emission fluxes, a threshold $1 \times 10^{-4} \mathrm{~kg} \mathrm{~m}^{-2}$ day $^{-1}$ was applied following the suggestion by Tegen et al. (2013). Similar to the DSAFs obtained from MSG observations for June-July 2013, DSAFs calculated from COSMO-MUSCAT simulations highlight a hotspot in terms of DSAFs for the source area located south of the Hoggar Massif and in between the Adra and Air mountains. Also, frequent dust emission from sources over southern Mauritania are simulated in agreement with the DSAF observations (see Fig. 1). However, the level of dust source activity is generally higher for COSMO-MUSCAT than observed, in particular over the Sahel zone. There, dust emission efficiency may be too high and thus dust source activation events too frequent compared to the observations. While satellite observations may be more susceptible to cloud biases over the Sahel, atmospheric dust loading over this region is overestimated by COSMO-MUSCAT. This is also suggested by the comparison against sun-photometer dust aerosol optical depth (AOD) estimates as discussed below. Lower modelled DSAFs compared to the observations are evident in particular for dust sources situated in mountain regions. Dust sources embedded in the foothills of the Saharan mountains are scarcely captured by COSMO-MUSCAT - the model's difficulty in simulating the local wind speed distribution over complex terrain at a horizontal resolution of $0.25^{\circ}$ is the main reason for this (see Tegen et al., 2013).

Similarly, dust aerosol optical depth representing the total atmospheric column dust load calculated from COSMOMUSCAT simulations (see Schepanski et al., 2016, for a description on the calculation) are compared against AOD estimates calculated from sun-photometer measurements, which are organized and made available through the AERONET (AErosol RObotic NETwork; Holben et al., 1998) initiative. AODs for five different stations directly influenced by Saharan dust plumes are selected: Santa Cruz located on the island of Tenerife $\left(28.473^{\circ} \mathrm{N}, 16.247^{\circ} \mathrm{W}\right.$; Spain $)$ off the coast of northwest Africa, Cabo Verde on the island of Sal $\left(16.733^{\circ} \mathrm{N}, 22.935^{\circ} \mathrm{W}\right.$; Cabo Verde) off the coast of West Africa, Dakar $\left(14.394^{\circ} \mathrm{N}, 16.959^{\circ} \mathrm{W}\right.$; Senegal) in the westernmost part of West Africa, and Cinzana $\left(13.278^{\circ} \mathrm{N}, 5.934^{\circ} \mathrm{W}\right.$; Mauritania) and Banizoumbou $\left(13.541^{\circ} \mathrm{N}, 2.665^{\circ} \mathrm{E}\right.$; Niger) situated in the Sahel and bordering to the southern margin of the Sahara. The five stations
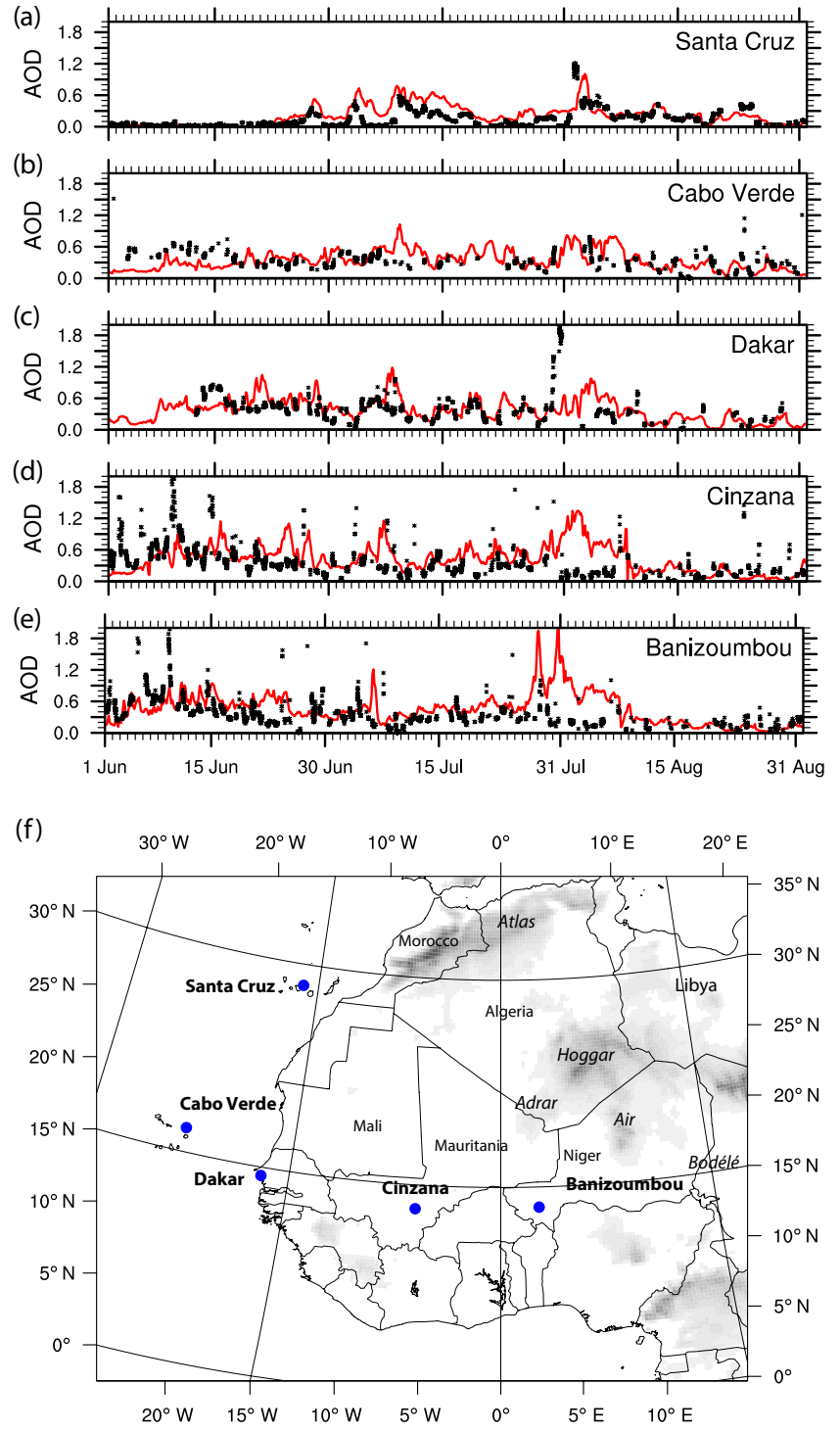

Figure 4. Dust AOD calculated from COSMO-MUSCAT dust concentration fields (red) and coarse-mode AOD estimated from AERONET sun-photometer measurements (black) for JJA 2013 at five different stations: (a) Santa Cruz $\left(28.473^{\circ} \mathrm{N}\right.$, $16.247^{\circ} \mathrm{W}$; Spain), (b) Cabo Verde $\left(16.733^{\circ} \mathrm{N}, 22.935^{\circ} \mathrm{W}\right.$; Cabo Verde), (c) Dakar $\left(14.394^{\circ} \mathrm{N}, 16.959^{\circ} \mathrm{W}\right.$; Senegal), (d) Cinzana $\left(13.278^{\circ} \mathrm{N}, 5.934^{\circ} \mathrm{W}\right.$; Mauritania), and (e) Banizoumbou $\left(13.541^{\circ} \mathrm{N} 2.665^{\circ} \mathrm{E}\right.$, Niger). An overview on the stations' geographic location and geographic names (AERONET site: bold; geographic names: italic; countries: roman) used in this publication are given in (f); orography is implied by grey shading.

are located downwind of the source regions and within the dust transport path towards the Atlantic. A more thorough validation of the model simulation including satellite products is published in Schepanski et al. (2016), which discusses Saharan dust transport towards the Mediterranean Basin. 

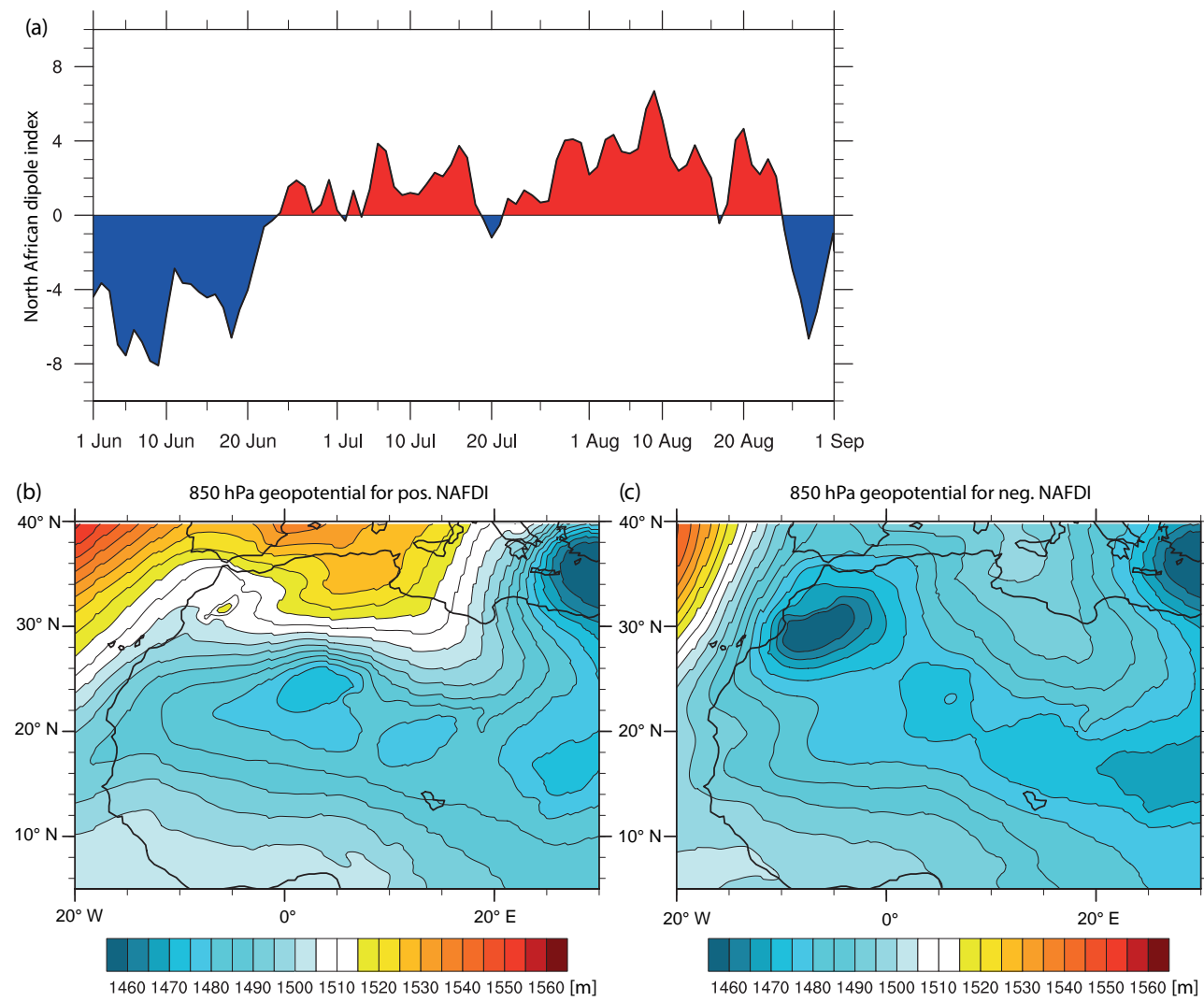

Figure 5. (a) North African dipole intensity index calculated following Eq. (1) reflecting the strength of the harmattan flow over North Africa. (b) Composite of $850 \mathrm{hPa}$ geopotential height $(\mathrm{m})$ days within the 75th percentile range of the NAFDI index values, and (c) for days within the 25th percentile range.

As the COSMO-MUSCAT AODs consider dust aerosols only in these simulations analysed here, sun-photometer measurements in contrast are affected by all types of aerosol particles (i.e. mineral dust, soot, sea spray aerosol), coarsemode AODs (O'Neill et al., 2003) predominantly represent the dust fraction. This is a common approach in order to allow for the best comparability with model simulations where mineral dust is the only simulated type of aerosol (Tegen et al., 2013; Schepanski et al., 2015b, 2016). The comparison of COSMO-MUSCAT dust AODs with AERONET coarsemode AODs as shown in Fig. 4 depicts the model's ability to simulate the temporal variability of the atmospheric dust load over the particular sites. The AERONET data used were cloud-screened and at quality level 2.0 (Santa Cruz, Dakar) or level 1.5 (Cabo Verde, Cinzana, Banizoumbou) where level 2.0 was not available. Generally, the model represents the range of AOD values and the temporal evolution of the coarse-mode AOD derived from sun-photometer measurements at these sites well, although some minor differences on a single-event basis are evident. This suggests that COSMO-MUSCAT sufficiently well captures the atmospheric dust life cycle including its relevant and determining atmospheric processes. In particular, matching dust AODs suggest that COSMO-MUSCAT is able to capture the meteorology correctly and, furthermore, to balance dust emission dust removal fluxes sufficiently well. The model results therefore are trustworthy for deriving the relations between the dust cycle and the drivers of atmospheric circulation in the study period.

\section{Atmospheric circulation modulating the atmospheric dust burden over North Africa}

In the following sections, the role of the harmattan, the SHL, and the WAM will be examined exemplarily for summer (June-August) 2013 with regard to their impact on the atmospheric dust load and dust transport towards the North Atlantic.

\subsection{Harmattan}

The strength of the harmattan, the name use for the trade winds over North Africa, is determined by the pressure gradient between the subtropics and the tropics. Due to the geographic situation, the gradient is strongest over the northern African continent. The northeasterly harmattan winds 

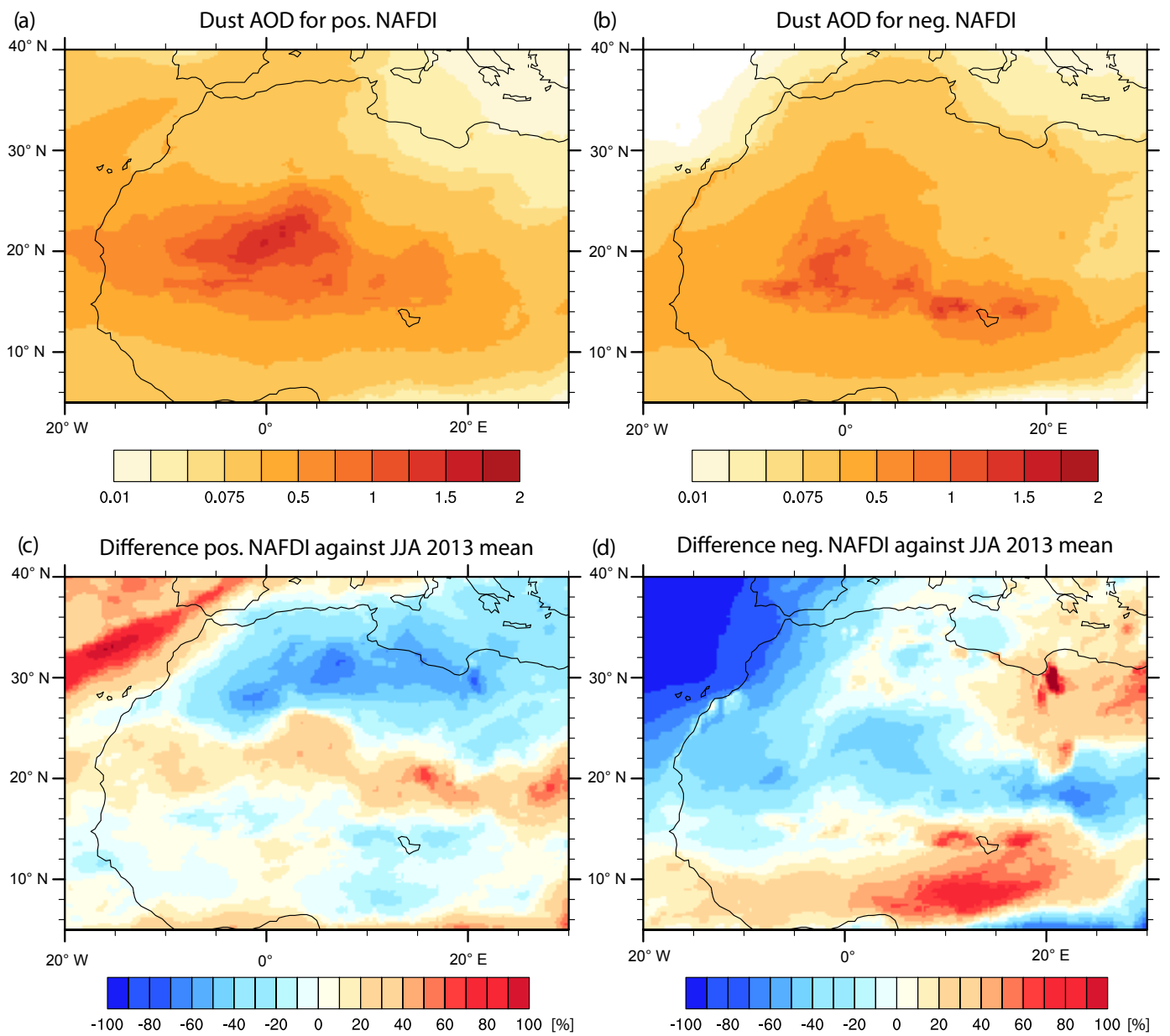

Figure 6. Composite of dust AOD for days within the 75th percentile (a) and 25th percentile (b) of the NAFDI index values. Panels (c) and (d) show the relative difference to the JJA 2013 mean.

are deflected by local topography and modulated by variability in pressure distribution. Rodríguez et al. (2015) introduced the North African dipole intensity (NAFDI) index in order to represent the temporal variability in the harmattan flow. The index is similar to the North Atlantic Oscillation (NAO) index, but represents the pressure gradient over the northern African continent, which is of direct relevance for the strength of the harmattan winds. The NAFDI is the normalized difference of the anomaly of the geopotential $\Phi$ at $700 \mathrm{hPa}$ between two $3^{\circ} \times 3^{\circ}$ boxes located north and south of the Sahara. For this study, the NAFDI index $F$ is calculated as follows:

$F=\frac{1}{10}\left(\left(\Phi_{\mathrm{n}}^{t}-\overline{\Phi_{\mathrm{n}}}\right)-\left(\Phi_{\mathrm{s}}^{t}-\overline{\Phi_{\mathrm{s}}}\right)\right)$

with $\Phi_{\mathrm{n}}$ denoting geopotential averaged over a box located north of the Sahara $\left(30-32^{\circ} \mathrm{N}, 5-7^{\circ} \mathrm{W}\right)$, and $\Phi_{\mathrm{s}}$ representing the geopotential averaged over a box located south of the Sahara $\left(10-13^{\circ} \mathrm{N}, 6-8^{\circ} \mathrm{W}\right)$. The index $t$ denotes the date out of the period 1 June to 31 August 2013, as the NAFDI values are calculated on a daily basis for this study. Temporal means $\Phi$ are calculated over the entire period, here JJA 2013.

The temporal evolution of the NAFDI index as shown in Fig. 5a for June to August 2013 reflects the intensity of the pressure gradient across the Sahara and thus the strength of the harmattan winds. The JJA 2013 summer season is characterized by for this period low NAFDI index values during the first 3 weeks. On 24 June the index switches from negative values to positive values and remains positive until $24 \mathrm{Au}-$ gust, with only brief intermittence. Regarding the strength and thus the predominance of the harmattan flow, JJA 2013 can roughly be separated into three phases. Phase I represents the period from 1 to 23 June, which is characterized by negative NAFDI index values. Phase II represents the period from 24 June to 24 August, which is dominated by positive NAFDI index values. Phase III, from 24 to 31 August, is characterized by negative index values again. To demonstrate the pressure distribution over North Africa corresponding to negative (or positive) NAFDI index values, composite plots for the 25th percentile and 75th percentile are compiled. Fig- 

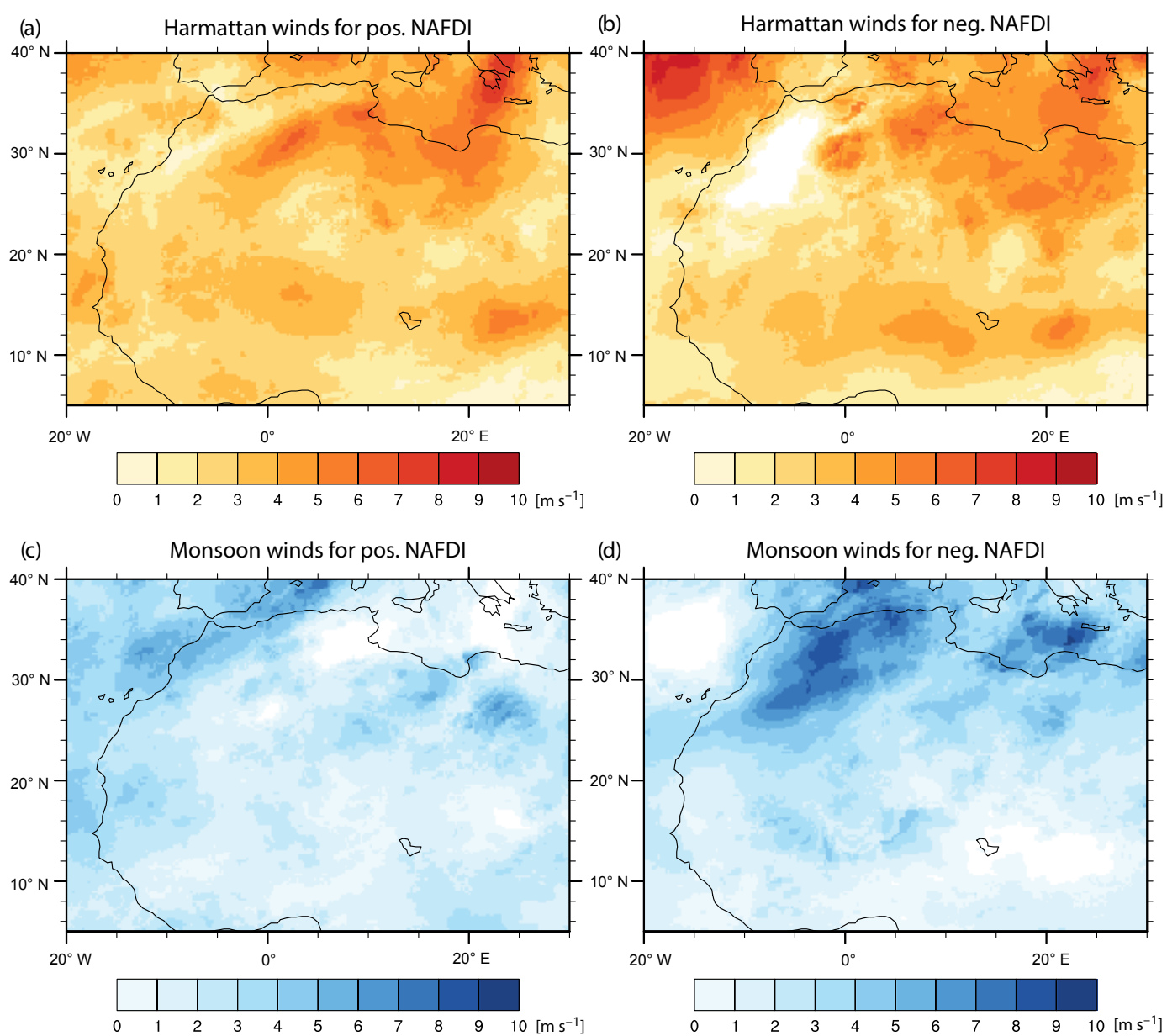

Figure 7. Composite of meridional winds for 75th percentile (positive values) and 25th percentile (negative values) of the NAFDI index values. The meridional winds $\left(\mathrm{ms}^{-1}\right)$ are shown separately for northerly winds referring to the harmattan (a, b), and southerly winds referring to the monsoon $(\mathbf{c}, \mathbf{d})$.

ure $5 \mathrm{~b}$ and c present the composites for the $850 \mathrm{hPa}$ geopotential calculated on the basis of these days, on which the NAFDI index is within the range of the 75th percentile and 25 th percentile respectively. The $850 \mathrm{hPa}$ level is chosen as winds on this level impact on both dust emission and dust transport. The 75th percentile represents the particularly positive NAFDI values, the 25 th percentile particularly negative NAFDI values. The JJA 2013 index median is slightly positive, 0.9. NAFDI index values above 2.7 are included in the 75th percentile, index values below -3.1 are included in the 25th percentile. The composites are based on the quartiles to achieve a clear contrast between the two phases. A similar approach is suggested by Rodríguez et al. (2015). Low NAFDI index values are associated with a SHL in its western position, generally low pressure over the Sahara, and a weak subtropical ridge over the Mediterranean basin. In contrast to this, high NAFDI index values reflect a pressure distribution characterized by a SHL in its eastern position, and a pronounced subtropical ridge over the Mediterranean Basin with an enhanced pressure gradient towards the SHL.
Similar to the distribution of the geopotential reflecting the atmospheric circulation at low level, composites are calculated for the atmospheric dust loading expressed as dust AOD (Fig. 6a and b) and the meridional wind components (Fig. 7). The AOD composites for low and high NAFDI index values address the question of a link between atmospheric dust load and NAFDI phase. To illustrate the difference in AOD during particularly low (or high) NAFDI phases to the JJA average, the relative differences are shown in Fig. $6 c$ and d. As the NAFDI is based on the pressure gradient and so is the wind determining dust entrainment and transport, composites of the meridional wind speed complement the relation between NAFDI and dust AOD. In order to distinguish between northeasterly harmattan and southwesterly monsoon inflow, the meridional wind components are considered separately for northerly (representing harmattan conditions) and southerly (representing monsoon conditions) winds (see Fig. 7). The composite shows the average wind speed for the corresponding wind direction over the selected time period. In agreement with a weaker harmattan for periods characterized by 

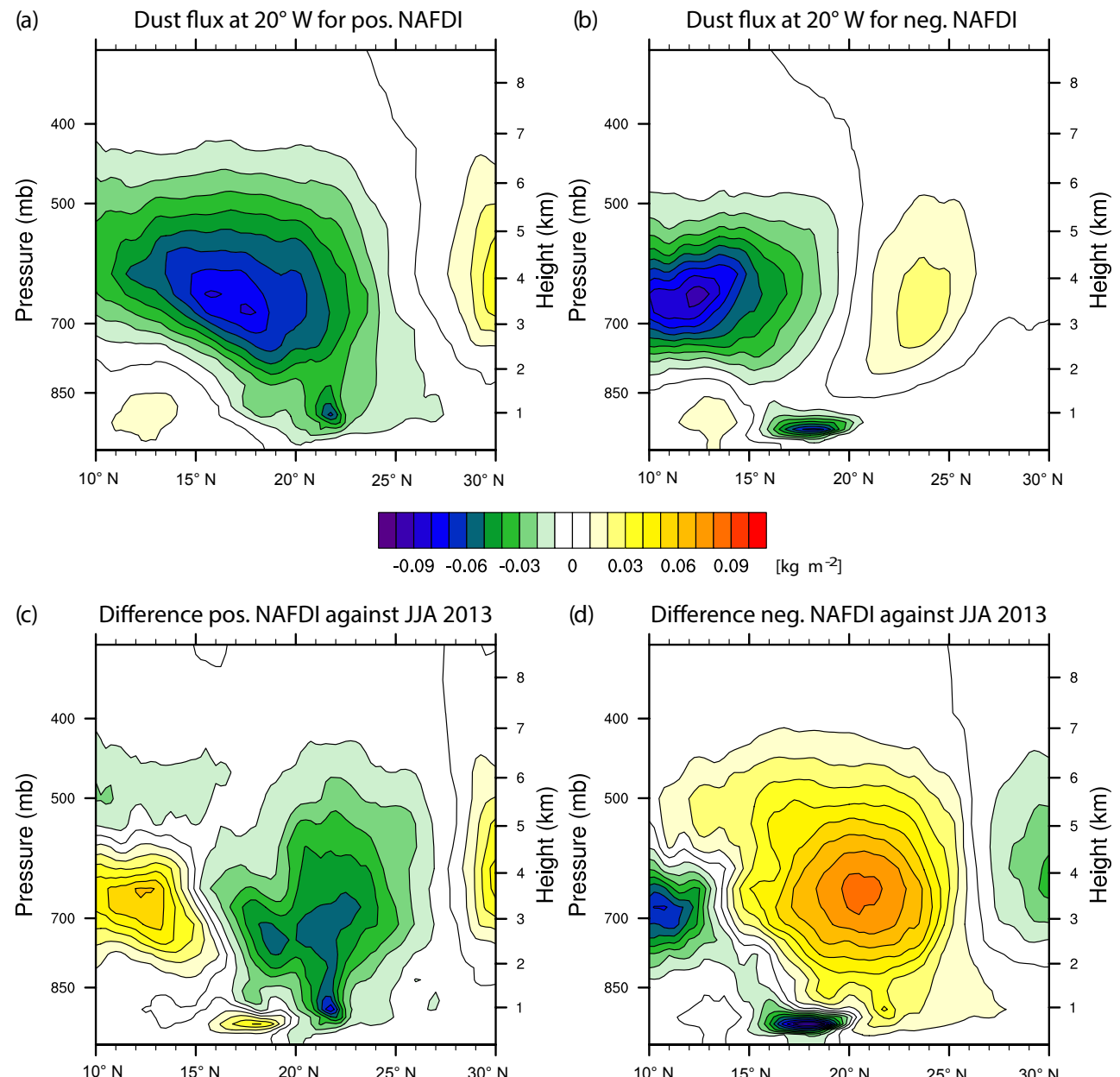

(d)
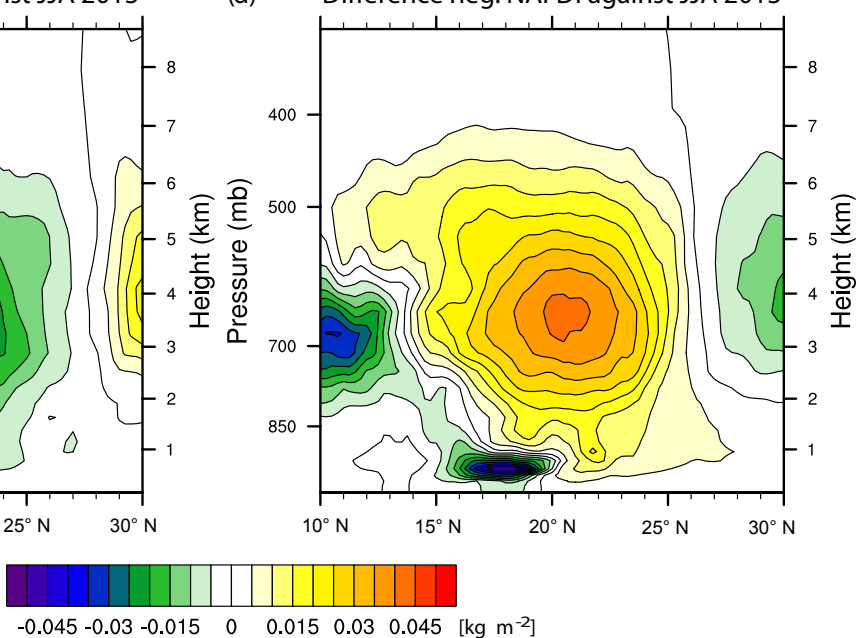

Figure 8. Composite plots of the vertically integrated zonal dust flux $\left(\mathrm{kg} \mathrm{m}^{-2}\right)$ at $20^{\circ} \mathrm{W}$ for the days of June, July, August 2013 , which correspond to the 75th percentile (a) and 25th percentile (b) of NAFDI index values. Dust export towards the North Atlantic is represented by negative values; positive values indicate transport back to the northern African continent. Dust fluxes are totals over the $10-25^{\circ} \mathrm{N}$ latitudinal band. Differences in dust flux compared against the JJA 2013 mean dust flux are shown in (c) and (d).

low NAFDI index values (Fig. 7), the dust plume over the Sahara extends further towards and into the Mediterranean Basin as southerly winds prevail (Fig. 6). As the pressure gradients are weaker, less dust is suspended in the atmosphere resulting in lower dust AOD values. During periods characterized by positive NAFDI index values, the atmospheric dust loading over the central Sahara at about $20-25^{\circ} \mathrm{N}$ is increased and so is the dust AOD over the dust outflow region off the West African coast. This situation is complemented by the dust export flux (Fig. 8), which shows that the core of the dust flux at $20^{\circ} \mathrm{W}$ is shifted to the south for days characterized by a particularly low (negative) NAFDI index. Furthermore, the recirculation of dust resulting in positive (eastward) dust fluxes at $20^{\circ} \mathrm{W}$ is enhanced compared to the JJA 2013 mean. The dust export (westward dust flux) is enhanced for days characterized by a positive NAFDI index representing strong harmattan winds.

\subsection{Saharan heat low}

The low-level atmospheric thickness (LLAT) between 925 and $700 \mathrm{hPa}$ is used to identify the SHL as suggested by Lavaysse et al. (2009). Thereby, the highest $10 \%$ of the LLAT values over North Africa $\left(0-40^{\circ} \mathrm{N}, 20^{\circ} \mathrm{W}-30^{\circ} \mathrm{E}\right)$ are defined as the SHL. During June and July, the centre of the SHL migrates from a mean position southwest of the Hoggar Massif to a more northwesterly position between the Atlas Mountains and the Hoggar Massif, where it remains quasistationary throughout July and August. The depth of the SHL increases throughout June and July reaching its maximum in July. The spatio-temporal evolution of the depth, extent, and 


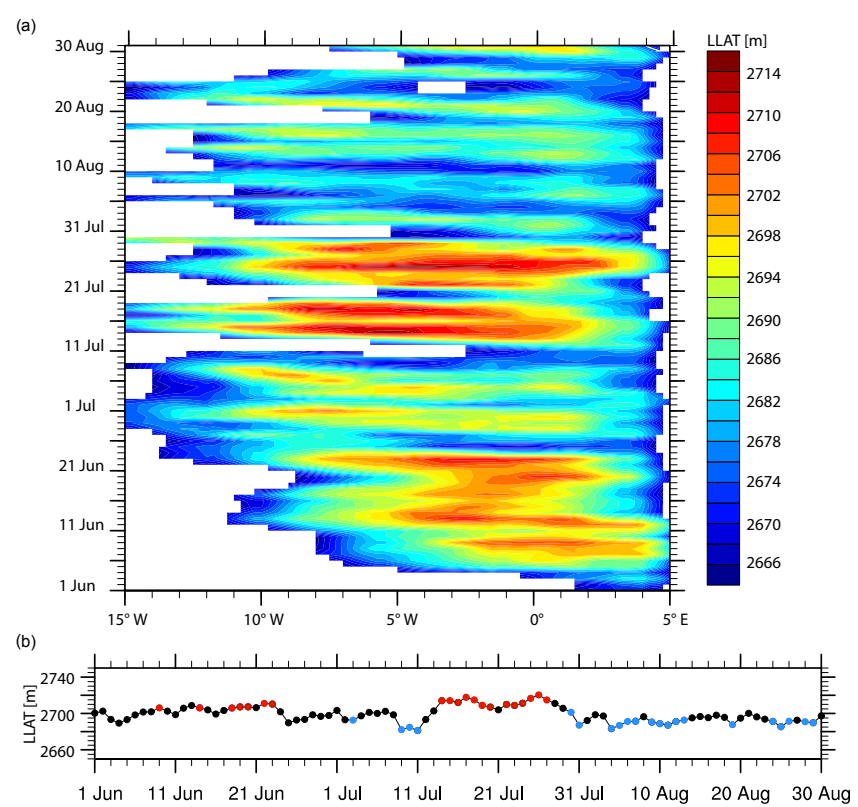

Figure 9. (a) Hovmöller diagram of low-level atmosphere thickness (LLAT) (m) representing the SHL at $23^{\circ} \mathrm{N}$. (b) Time series of maximum LLAT (m) for June to August 2013. Blue circles indicate daily LLAT maximum values less than the 25 th percentile, red circles indicate daily LLAT maximum values above the 75 th percentile. The LLAT is calculated from COSMO-MUSCAT simulation following Lavaysse et al. (2009).

geographical position of the centre can be summarized by a Hovmöller plot as shown in Fig. 9a. The maximum depth of the LLAT indicating the SHL is illustrated as time series in Fig. 9b. The individual LLAT maximum values show little variability over the course of the summer (JJA), as the SHL itself exists over the entire period over North Africa. However, the geographic position of the centre of the SHL is migrating. The SHL is characterized by a more southerly position during June and deepens throughout June reaching its maximum in 2013 during the second half of July (23 July 2013 , LLAT $=2720 \mathrm{~m}$ ) as expected. The deepening and northwestward propagation of the SHL is of intermittent nature showing phases of increasing depth and northward propagation and phases of a southward retreat and decreasing intensity. Throughout the June to August 2013 period, the LLAT indicating the depth and thus the strength of the SHL varies around an average value of $2699 \mathrm{~m}$ with a standard deviation of $77 \mathrm{~m}$. During JJA 2013, two phases of a particular deep SHL occurred: a first but weaker period of LLAT maxima above the 75 th percentile $(2706 \mathrm{~m})$ occurred during 18 to 23 June, although the LLAT maxima did not reach similarly high values, mainly as this period is earlier during the summer season. A second and significantly stronger phase occurred between 14 and 28 July 2013, the period which also includes the overall maximum LLAT depth for that summer. The LLAT maximum values were continuously above the 75th percentile, except for one day (21 July). The second, stronger SHL phase is framed by two periods of a significantly shallow SHL with LLAT maximum values below the 25th percentile ( $2692 \mathrm{~m}$ ) between 9 and 11 July and between 31 July and 13 August. The latter phase was briefly intercalated by 3 days of increased LLAT values; however, the generally shallow extent of the SHL dominated.

The dust AOD distribution varies among the different strengths of the SHL, which is illustrated in Fig. 10 for the 75th percentile (a) and 25th percentile (b) of the LLAT respectively. A particularly deep and strong SHL (75th percentile) is accompanied by higher dust AODs over the central Sahara compared to a particularly shallow and therefore weak SHL, which is accompanied by a generally lower AOD levels. Regarding the dust export towards the east Atlantic, the dust outflow region is slightly shifted to the south for the stronger SHL condition; however, the dust AODs corresponding to the dust outflow region are at a comparable level. Comparing the dust AOD distribution for these two contrasting SHL conditions, significant differences are evident. The differences are strongest north of $35^{\circ} \mathrm{N}$, where the dust AOD level is significantly enhanced over the Atlas region due to the unusual northward extent of the Saharan dust plume during strong SHL conditions (Fig. 10a and c). Also, the level of dust AOD is enhanced over the southern Sahara and Sahel zone (south of $20^{\circ} \mathrm{N}$ ). This may be due to stronger winds along the southern margin of the SHL caused by an enhanced pressure gradient. During conditions with a particularly weak SHL (25th percentile), the level of dust AOD over North Africa is generally lower, except for an intermittent region at around $20^{\circ} \mathrm{N}$. Particularly low AOD levels are evident over coastal Libya, associated with the generally low atmospheric dust load over that region (Fig. 10b and d). This may be due to the more southerly position of the SHL during these periods.

\subsection{West African monsoon}

The West African monsoon circulation is driven by the Hadley circulation and supported by the gradients in temperature and humidity resulting from the contrast between the hot and dry Sahara and the humid and cooler Gulf of Guinea (Parker et al., 2005a). To illustrate the intermittent nature of the northward propagation of the monsoonal air, Fig. 11 shows the northward propagation of the humid monsoonal air summarized by the Hovmöller diagram. The northward transport of monsoonal, humid air through $20^{\circ} \mathrm{N}$ is expressed as the northward flux of humidity, calculated as product of the specific humidity and the northward wind speed at nearsurface level ( $10 \mathrm{~m}$ above ground). At $20^{\circ} \mathrm{N}$, the monsoonal air arrives in pulses, which reflect the intermittent character of the northward pushes of the monsoon front and illustrates the non-stationarity of the WAM circulation. The observed intermittency agrees with the impact of the passage of AEW and associated troughs over this region. However, a 

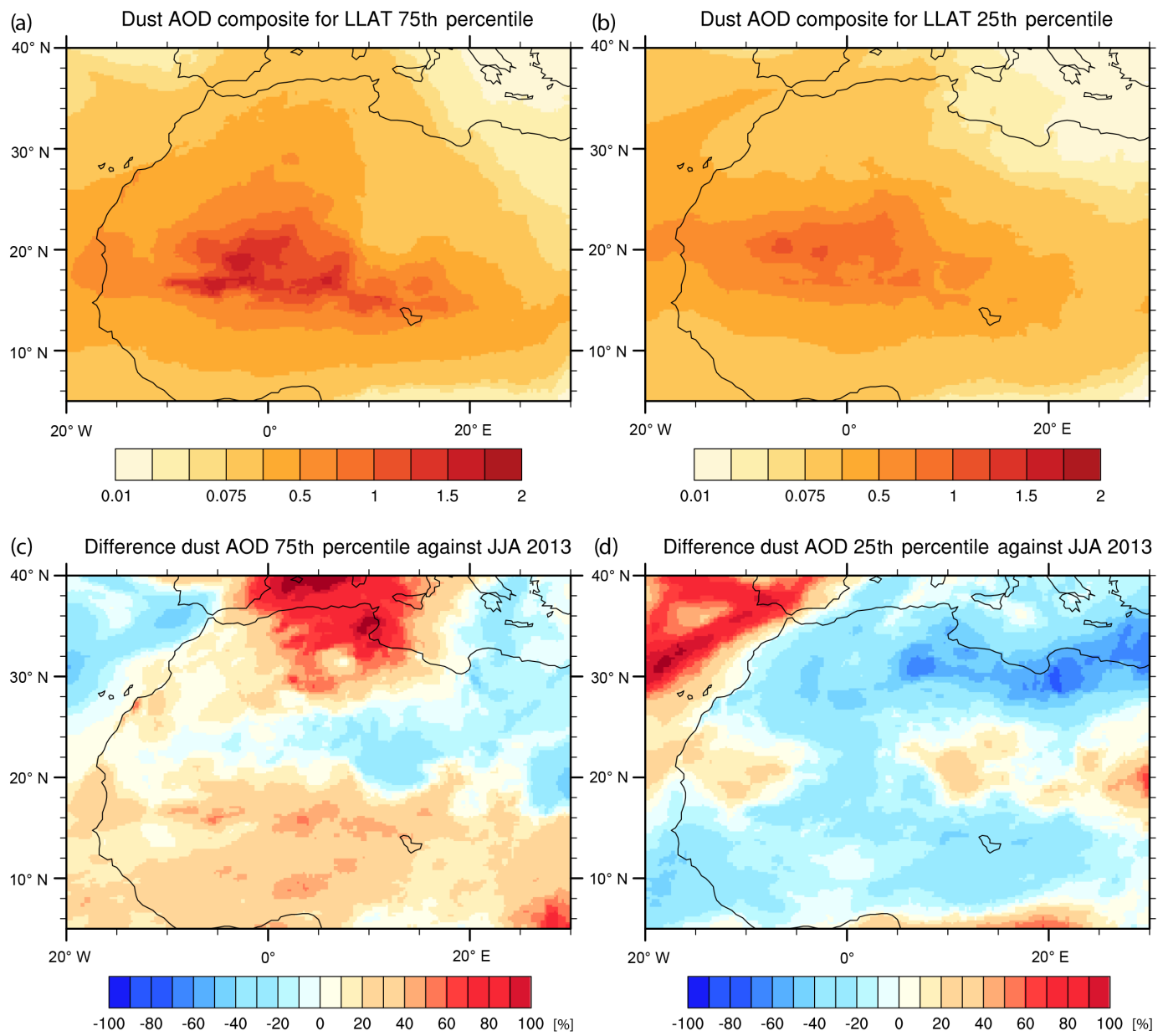

Figure 10. Composite of dust AOD for the days corresponding to the 75th percentile (a) and 25th percentile (b) of the LLAT. See Fig. 9 for the assignment of the days to the 25th and 75th percentile; panels (c) and (d) show the relative difference to the JJA 2013 mean.

clear relation between the intensity or frequency of the monsoon front's northward propagation and the NAFDI or LLAT index is not apparent. The temporal evolution rather illustrates the pre-monsoon phase until the end of June and the onset of the monsoon in July. During its peak, monsoonal air propagates as far north as $20^{\circ} \mathrm{N}$. Figure $7 \mathrm{c}$ and d illustrate the monsoonal (southerly) winds over North Africa on days corresponding to positive (or negative) NAFDI index values. Although including no information on the actual humidity of the air mass, the meridional wind direction and thus the origin of the air mass implies the predominance of monsoonal air. For example, on days characterized by particularly negative NAFDI index values, the southerly winds are apparent southwest of the central Saharan mountains. This region is also identified as major dust source region during the second half of the day (see Sect. 4 and Fig. 2) probably activated by deep-moist convection embedded in the monsoonal air.

\section{Discussion and implications for dust transport and export}

Dust transport and dust export are closely related. Both are describing the flux of dust within the air: prevailing wind regimes determine transport pathways, and deposition and sedimentation velocities determine dust removal rates from the atmosphere. In the context of this study, dust export is considered as the dust transport towards the ocean and thus off the northern African continent, e.g. through $20^{\circ} \mathrm{W}$ as a simplified representation of the West African coast line. The zonal flux $M_{z}$ is calculated as the product of zonal wind velocity $v$ and dust concentration $c$ :

$M_{z}=v \cdot c$.

The objective of this study was set to investigate the atmospheric controls on the atmospheric dust life cycle with particular focus on the dust export towards the Atlantic and ultimately towards the Caribbean Sea. Apparently, dust emission and transport pathways over the northern African con- 


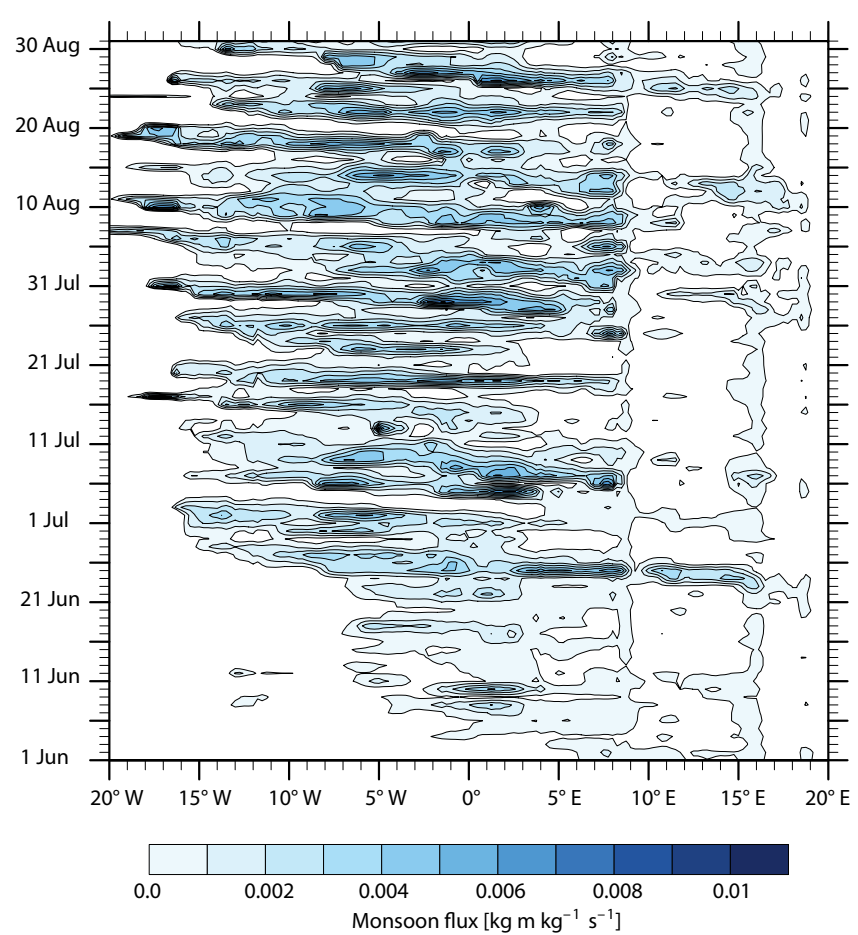

Figure 11. Meridional monsoon flux $\left(\mathrm{kg} \mathrm{m} \mathrm{kg}^{-1} \mathrm{~s}^{-1}\right)$ at $20^{\circ} \mathrm{N}$ at surface level calculated as the product of the northward component of the meridional wind and the specific humidity, both at $10 \mathrm{~m}$ above ground level.

tinent determine the dust export. The amount of dust crossing the $20^{\circ} \mathrm{W}$ meridian is characterized by a function of latitude, vertical height, and time describing the intermittent nature of the dust flux towards the eastern North Atlantic. Figure 12 presents its variability over time for June to $\mathrm{Au}-$ gust 2013. The figure panels (Fig. 12a and b) are complementary: Fig. 12a illustrates the predominant height of dust transport, but does not distinguish for different latitudes. Figure $12 \mathrm{~b}$ shows the variability of the vertically integrated dust transport fluxes over the different latitudes disregarding the variability in transport height.

The height of dust transport through $20^{\circ} \mathrm{W}$ is crucial for the cross-Atlantic transport. Dust transported within the SAL, which is situated above the trade wind inversion at heights between 800 and $500 \mathrm{hPa}$, is often described as the transport highway for dust across the Atlantic. Whereas dust transported within the marine boundary layer shows enhanced dust removal rates, and consequently high deposition fluxes, dust transport within the SAL is more efficient and higher dust concentrations are more likely to reach the Caribbean. Generally, dust export within the SAL is characteristic for the summer season (e.g. Schepanski et al., 2009a).

Considering Fig. 12a and b together, JJA 2013 dust transport through $20^{\circ} \mathrm{W}$ occurred predominantly within the SAL and showed an intermittent character, which is typical for summertime dust export (Jones et al., 2003; Schepanski et al., 2009a). The intermittent character of dust plumes or dust pulses leaving the northern African continent and entering the Atlantic becomes also evident when considering the dust flux through $20^{\circ} \mathrm{W}$ as a function of latitude and time (Fig. 12b). The major fraction of dust mass being transported westwards is leaving North Africa between 12 and $23^{\circ} \mathrm{N}$. Recirculating dust plumes may enter the northern African continent again to the north or south of the SAL core, particularly at around $25^{\circ} \mathrm{N}$.

This study aimed at investigating the North African dust outflow and consequent dust export towards the North Atlantic depending on the atmospheric circulation present over North Africa. To cluster similar circulation regimes characterized by different strengths of the major atmospheric elements, namely harmattan, SHL, and WAM, different indices were presented (see Sect. 6). Figure 13 presents the temporal evolution of the harmattan circulation represented by the NAFDI index and the LLAT representing the SHL together with the westward (negative values) an eastward (positive values) dust flux through $20^{\circ} \mathrm{W}$. We focus on the NAFDI and LLAT only as these two indices are directly linked to the wind regime over the northern African continent. The humidity flux used as indicator for the northward propagation of the WAM is not included here as it is not directly representing the pressure or wind field resulting in dust emission and dust transport. As the individual time series for NAFDI, LLAT, and dust flux are presented above, the coincidence of individual phases of particular high or low index values are in focus. Generally, the Pearson correlation $r$ between NAFDI or LLAT and eastward or westward dust flux is close to zero ( $r$ (NAFDI, eastward dust flux $)=-0.04$, $r$ (NAFDI, westward dust flux $)=-0.3, r$ (LLAT, eastward dust flux $)=0.3, r$ (LLAT, westward dust flux $)=-0.1)$ and thus not significant. Overall and despite the intermittent character of the dust export flux, the westward dust flux is enhanced during the period characterized by positive NAFDI index values, which represent a distinct harmattan due to an enhanced pressure gradient across West Africa. Comparing dust flux and SHL intensity represented by the LLAT, it is noticeable that the pronounced reduction in westward dust flux coincides with the sudden reduction of the LLAT on 21 June 2013. Enhanced levels of westward dust export fluxes match with a diminishing LLAT. The maximum westward dust export matches with the diminishing phase following the LLAT maximum. Nevertheless, the correlation is below level of confidence and suggests that the relation between NAFDI, LLAT, and dust flux is not as robust as expected. One reason explaining this may be the temporal lag with which the harmattan winds and SHL intensity act on the dust export. 

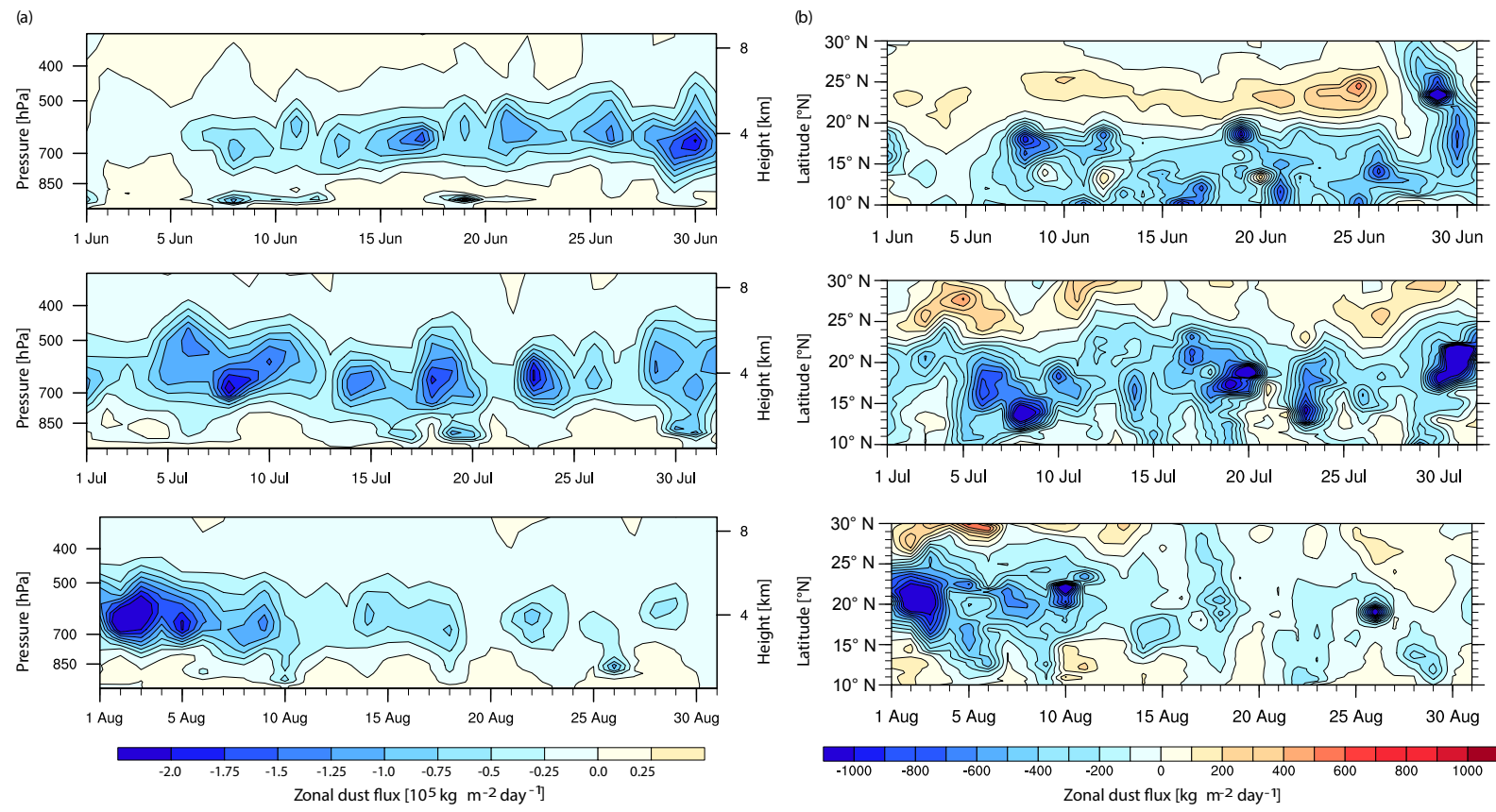

Figure 12. (a) Zonal dust flux $\left(\mathrm{kg} \mathrm{m}^{-2} \mathrm{day}^{-1}\right)$ at $20^{\circ} \mathrm{W}$. Dust export towards the North Atlantic is represented by negative values; positive values indicate transport back to the northern African continent. Dust fluxes are totals over the $10-25^{\circ} \mathrm{N}$ latitudinal band. (b) Zonal dust flux $\left(\mathrm{kg} \mathrm{m}^{-2} \mathrm{day}^{-1}\right)$ at $20^{\circ} \mathrm{W}$. Dust export towards the North Atlantic is represented by negative values; positive values indicate transport back to the northern African continent. Dust fluxes are totals over the vertical column $(0-22 \mathrm{~km})$.

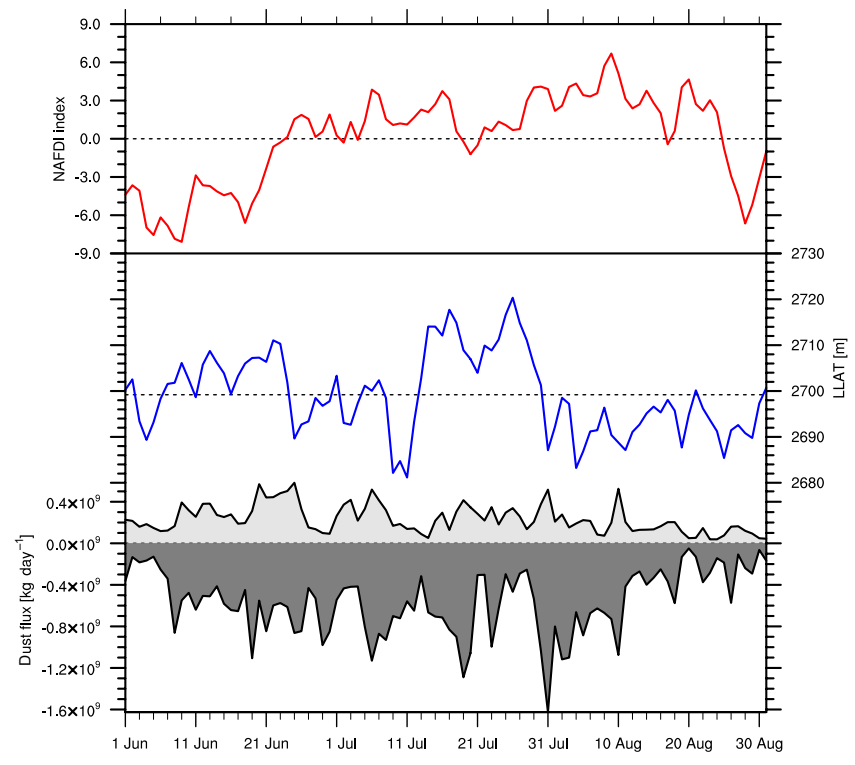

Figure 13. Time series of the NAFDI index (red) indicating the strength of the harmattan, the LLAT (blue) representing the depth of the SHL, and the westward (dark grey) and eastward (light grey) dust flux at $20^{\circ} \mathrm{W}$ integrated over the total column $(0-22 \mathrm{~km}$ altitude) and the latitudinal band between 10 and $25^{\circ} \mathrm{N}$.

\section{Conclusions}

Harmattan, Saharan heat low, and West African monsoon are the three major elements of the atmospheric circulation over North Africa, the most active and most contributing dust source region on Earth. The source regions are active throughout the year and a constant outflow of dust leaving the continent can be observed. During summer, a continuous flow of dust crossing the North Atlantic towards the Caribbean is apparent and described by the SAL. However, in addition to this background flow of dust, intermittent events of enhanced dustiness occur. They are described by dust plumes or pulse of dust that can be impressively visualized by satellite images. This study aimed at investigating the impact of the three major elements determining the atmospheric circulation over North Africa on the variability of the dust outflow, which can be understood as an amplification over the background flow. To achieve this, the variability of each element was described by different methods described in the literature. The temporal variability of the strength of the harmattan was described by the NAFDI index (Rodríguez et al., 2015), the SHL was described by the LLAT (Lavaysse et al., 2009), and the WAM inflow was identified by corresponding moisture flux as shown by Parker et al. (2005a). The dust flux through $20^{\circ} \mathrm{N}$ was defined here as the ultimate measure to quantify the temporal variability of the dust export towards the North Atlantic. All three methods describing the variability of the individual circulation element were 
compared against the variability in the dust flux. Although each method identified phases of enhanced and weak activity of the corresponding meteorological element, the temporal agreement among them is only evident for individual periods. This may be due to the timescale of the study, which focused on daily effects rather than climatological evidence or tendencies. Findings from the present study are limited to the specific situation of summer 2013. However, the results suggest to consider the impact of the elements of the atmospheric circulation over North Africa on the dust export as a modulation on top of the background dust outflow, in which the effects of the individual elements are supposed.

Data availability. COSMO-MUSCAT data are available on request. The dust source activation frequency (DSAF) data set is published under https://doi.org/10.14759/41916.2016.1. AERONET coarse-mode AODs are available from http://aeronet.gsfc.nasa.gov.

Competing interests. The authors declare that they have no conflict of interest.

Special issue statement. This article is part of the special issue "The Saharan Aerosol Long-range Transport and Aerosol-Cloudinteraction Experiment (SALTRACE) (ACP/AMT inter-journal SI)". It is not associated with a conference.

Acknowledgements. Kerstin Schepanski acknowledges funding through the Leibniz Association for the project "Dust at the interface - modelling and remote sensing". The authors thank the two anonymous reviewers for their valuable input. Further thanks are due to the Deutscher Wetterdienst (DWD) for cooperation and support and the AERONET team from the sites at Santa Cruz de Tenerife, Cabo Verde, Dakar, Cinzana, and Banizoumbou for obtaining the measurements and providing the data.

Edited by: Cyrille Flamant

Reviewed by: two anonymous referees

\section{References}

Ansmann, A., Petzold, A., Kandler, K., Tegen, I., Wendisch, M., Müller, D., Weinzierl, B., Müller, T., and Heintzenberg, J.: Saharan Mineral Dust Experiments SAMUM-1 and SAMUM-2: what have we learned?, Tellus, 63B, 403-429, https://doi.org/10.1111/j.1600-0889.2011.00555.x, 2011.

Ashpole, I. and Washington, R.: Intraseasonal variability and atmospheric controls on daily dust occurrence frequency over the central and western Sahara during the boreal summer, J. Geophys. Res., 118, 12915-12926, https://doi.org/10.1002/2013JD020267, 2013.

Banks, J. R., Brindley, H. E., Stenchikov, G., and Schepanski, K.: Satellite retrievals of dust aerosol over the Red Sea and the Per- sian Gulf (2005-2015), Atmos. Chem. Phys., 17, 3987-4003, https://doi.org/10.5194/acp-17-3987-2017, 2017.

Bergametti, G., Rajot, J. L., Pierre, C., Bouet, C., and Marticorena, B.: How long does precipitation inhibit wind erosion in the Sahel?, Geophys. Res. Lett., 43, 6643-6649, https://doi.org/10.1002/2016GL069324, 2016.

Berge, E.: Transboundary air pollution in Europe. In: MSC-W Status Report 1997, Part 1 and 2, EMEP/MSC-W Report 1/97, The Norwegian Meteorological Institute, Oslo, Norway, 1997.

Bou Karam, D., Flamant, C., Knippertz, P., Reitebuch, O., Pelon, J., Chong, M., and Dabas, A.: Dust emissions over the Sahel associated with the West African monsoon intertropical discontinuity region: A representative case-study, Q. J. Roy. Meteor. Soc., 134, 621-634, https://doi.org/10.1002/qj.244, 2008.

Bou Karam, D., Flamant, C., Tulet, P., Chaboureau, J.-P., Dabas, A., and Todd, M. C.: Estimate of Sahelian dust emissions in the intertropical discontinuity region of the West African Monsoon, J. Geophys. Res., 114, D13106, https://doi.org/10.1029/2008JD011444, 2009.

Bou Karam, D., Flamant, C., Cuesta, J., Pelon, J., and Williams, E.: Dust emission and transport associated with a Saharan depression: February 2007 case, J. Geophys. Res., 115, D00H27, https://doi.org/10.1019/2009JD012390, 2010.

Brindley, H. E., Knippertz, P., Ryder, C., and Ashpole, I.: A critical evaluation of the ability of the Spinning Enhanced Visible and Infrared Imager (SEVIRI) thermal infrared red-green-blue rendering to identify dust events: Theoretical analysis, J. Geophys. Res., 117, D07201, https://doi.org/10.1029/2011JD017326, 2012.

Carslaw, K. S., Boucher, O., Spracklen, D. V., Mann, G. W., Rae, J. G. L., Woodward, S., and Kulmala, M.: A review of natural aerosol interactions and feedbacks within the Earth system, Atmos. Chem. Phys., 10, 1701-1737, https://doi.org/10.5194/acp10-1701-2010, 2010.

Chaboureau, J.-P., Flamant, C., Dauhut, T., Kocha, C., Lafore, J.P., Lavaysse, C., Marnas, F., Mokhtari, M., Pelon, J., Reinares Martínez, I., Schepanski, K., and Tulet, P.: Fennec dust forecast intercomparison over the Sahara in June 2011, Atmos. Chem. Phys., 16, 6977-6995, https://doi.org/10.5194/acp-166977-2016, 2016.

Chauvin, F., Roehrig, R., and Lafore, J.-P.: Intraseasonal Variability of the 2544-2561, https://doi.org/10.1175/2010JCLI3093.1, 2010.

Crouvi, O., Schepanski, K., Amit, R., Gillespie, A. R., and Enzel, Y.: Multiple dust sources in the Sahara desert: The importance of sand dunes, Geophys. Res. Lett., 39, L13401, https://doi.org/10.1029/2912GL052145, 2012.

Fiedler, S., Schepanski, K., Heinold, B., Knippertz, P., and Tegen, I.: Climatology of nocturnal low-level jets over North Africa and implications for modelling mineral dust emission, J. Geophys. Res., 118, 6100-6121, https://doi.org/10.1002/jgrd.50394, 2013.

Fiedler, S., Schepanski, K., Knippertz, P., Heinold, B., and Tegen, I.: How important are atmospheric depressions and mobile cyclones for emitting mineral dust aerosol in North Africa?, Atmos. Chem. Phys., 14, 8983-9000, https://doi.org/10.5194/acp14-8983-2014, 2014.

Formenti, P., Caquineau, S., Desboeufs, K., Klaver, A., Chevaillier, S., Journet, E., and Rajot, J. L.: Mapping the physicochemical properties of mineral dust in western Africa: miner- 
alogical composition, Atmos. Chem. Phys., 14, 10663-10686, https://doi.org/10.5194/acp-14-10663-2014, 2014.

Ginoux, P., Prospero, J. M., Gill, T. E., Hsu, N. C., and Zhao, M.: Global-scale attribution of anthropogenic and natural dust sources and their emission rates based on MODIS Deep Blue aerosol products, Rev. Geophys., 50, RG3005, https://doi.org/10.10129/2012RG000388, 2012.

Grams, C. M., Jones, S. C., Marsham, J. H., Parker, D. J., Haywood, J. M., and Heuveline, V.: The Atlantic Inflow to the Saharan heat low: Observations and Modelling, Q. J. Roy. Meteor. Soc., 136, 125-140, https://doi.org/10.1002/qj.429, 2010.

Groß, S., Freudenthaler, V., Schepanski, K., Toledano, C., Schäfler, A., Ansmann, A., and Weinzierl, B.: Optical properties of long-range transported Saharan dust over Barbados as measured by dual-wavelength depolarization Raman lidar measurements, Atmos. Chem. Phys., 15, 11067-11080, https://doi.org/10.5194/acp-15-11067-2015, 2015.

Heinold, B., Tegen, I., Schepanski, K., Tesche, M., Esselborn, M., Freudenthaler, V., Gross, S., Kandler, K., Knippertz, P., Müller, D., Schladitz, A., Toledano, C., Weinzierl, B., Ansmann, A., Althausen, D., Müller, T., Petzold, A., and Wiedensohler, A.: Regional modelling of Saharan dust and biomass-burning smoke, Part 1: Model description and evaluation, Tellus, 63B, 781-799, https://doi.org/10.1111/j.1600-0889.2011.00570.x, 2011.

Heinold, B., Knippertz, P., Marsham, J. H., Fiedler, S., Dixon, N. S., Schepanski, K., Laurent, B., and Tegen, I.: The role of deep convection and nocturnal low-level jets for dust emission in summertime West Africa: Estimates from convectionpermitting simulations, J. Geophys. Res., 118, 4385-4400, https://doi.org/10.1002/jgrd.50402, 2013.

Heinold, B., Schepanski, K., Gieseler, D., and Tegen, I.: Mixing and Deposition Processes during Transatlantic Transport of Saharan Dust, Atmos. Chem. Phys. Discuss., in preparation, 2017.

Heintzenberg, J.: The SAMUM-1 experiment over Southern Morocco: overview and introduction, Tellus, 61B, 2-11, https://doi.org/10.1111/j.1600-0889.2008.00403.x2009

Holben, B. N., Eck, T. F., Slutsker, I., Tanré, D., Buis, J. P., Setzer, A., Vermote, E., Reagan, J. A., Kaufman, Y. J., Nakajima, T., Lavenu, F., Jankowiak, I., and Smirnov, A.: AERONET - A federated instrument network and data archive for aerosol characterization, Remote Sens. Environ., 66, 1-16, 10.1016/S00344257(98)00031-5, 1998.

Huneeus, N., Schulz, M., Balkanski, Y., Griesfeller, J., Prospero, J., Kinne, S., Bauer, S., Boucher, O., Chin, M., Dentener, F., Diehl, T., Easter, R., Fillmore, D., Ghan, S., Ginoux, P., Grini, A., Horowitz, L., Koch, D., Krol, M. C., Landing, W., Liu, X., Mahowald, N., Miller, R., Morcrette, J.-J., Myhre, G., Penner, J., Perlwitz, J., Stier, P., Takemura, T., and Zender, C. S.: Global dust model intercomparison in AeroCom phase I, Atmos. Chem. Phys., 11, 7781-7816, https://doi.org/10.5194/acp11-7781-2011, 2011.

Jakobson, H. A., Jonson, J. E., and Berge, E.: The multi-layer Eulerian model: model description and evaluation of transboundary fluxes of sulphur and nitrogen species for one year. EMEP/MSCW, Note 2/97, The Norwegian Meteorological Institute, Oslo, Norway, 1997.

Jones, C., Mahowald, N., and Luo, C.: The role of easterly waves on African desert dust transport, J. Climate, 16, 3617-3628, https://doi.org/10.1175/1520-0442(2003)016, 2003.
Knippertz, P., Ansmann, A., Althausen, D., Müller, D., Tesche, M., Bierwirth, E., Dinter, T., Müller, T., von Hoyningen-Huene, W., Schepanski, K., Wendisch, M., Heinold, B., Kandler, K., Petzold, A., Schütz, L., and Tegen, I.: Dust mobilization and transport in the northern Sahara during SAMUM 2006 - A meteorological overview, Tellus B, 61, 1231, https://doi.org/10.1111/j.16000889.2008.00380.x, 2009.

Klose, M. and Shao, Y.: Large-eddy simulation of turbulent dust emission, Aeolian Res., 8, 49-58, https://doi.org/10.1016/j.aeolia.2012.10.010, 2013.

Kocha, C., Tulet, P., Lafore, J.-P., and Flamant, C.: The importance of the diurnal cycle of Aerosol Optical Depth in West Africa, Geophys. Res. Lett., 40, 785-790, https://doi.org/002/grl.50143, 2013.

Kok, J. F., Parteli, E. J. R., Michaels, T. I., and Bou Karam, D.: The physics of wind-blown sand and dust, Rep. Prog. Phys., 75, 106901, https://doi.org/10.1088/0034-4885/75/10/106901, 2012.

Lavaysse, C., Flamant, C., Janicot, S., Parker, D. J., Lafore, J.-P., Sultan, B., and Pelon, J.: Seasonal evolution of the West African heat low: a climatological perspective, Clim. Dynam., 33, 313 330, https://doi.org/10.1007/s00382-009-0553-4, 2009.

Lavaysse, C., Flamant, C., and Janicot, S.: Regional-scale convection patterns during strong and weak phases of the Saharan heat low, Atmos. Sci. Lett., 11, 255-264, https://doi.org/10.1002/asl.284, 2010.

Mahowald, N., Baker, A., Bergametti, G., Brooks, N., Duce, R., Jickells, T., Kubilay, N., Prospero, J., and Tegen, I.: Atmospheric global dust cycle and iron inputs to the ocean, Global Biogeochem. Cy., 19, GB4025, https://doi.org/10.1029/2004GB002402, 2005.

McConnell, C. L., Highwood, E. J., Coe, H., Formenti, P., Anderson, A., Osborne, S., Nava, S., Desboeufs, K., Chen, G., and Harrison, M. A. J.: Seasonal variations of the physical and optical characteristics of Saharan dust: Results from the Dust Outflow and Deposition to the Ocean (DODO) experiment, J. Geophys. Res., 113, D14, https://doi.org/10.1029/2007JD009606, 2008.

Menut, L., Forêt, G., and Bergametti, G.: Sensitivity of mineral dust concentrations on the model size distribution accuracy, J. Geophys. Res., 112, D10210, https://doi.org/10.1029/2006JD007766, 2007.

Morman, S. A. and Plumlee, G. S.: The role of airborne mineral dusts in human disease, Aeolian Res., 9, 203-212, https://doi.org/10.1016/j.aeolia.2012.12.001, 2013.

Okin, G. S., Mahowald, N., Chadwick, O. A., and Artaxo, P. P.: Impact of desert dust on the biogeochemistry of phosphorus in terrestrial ecosystems, Global Biogeochem. Cycle, 18, GB2005, https://doi.org/10.1029/2003GB002145, 2004.

O’Neill, N. T., Eck, T. F., Smirnov, A., Holben, B. N., and Thulasiraman, S.: Spectral discrimination of coarse and fine mode optical depth, J. Geophys. Res., 108, 4559, https://doi.org/10.1029/2002JD002975, 2003.

Parker, D. J., Burton, R., Diongue-Niang, A., Ellis, R., Felton, M., Taylor, C., Thorncroft, C., Bessemoulin, P., and Tompkins, A.: The diurnal cycle of the West African monsoon circulation, Q. J. Roy. Meteor. Soc., 131, 2839-2860, https://doi.org/10.1256/qj.04.52, 2005a.

Parker, D. J., Thorncroft, C. D., Burton, R., and Diongue-Niang, A.: Analysis of the African easterly jet using aircraft observa- 
tions from the JET2000 experiment, Q. J. Roy. Meteor. Soc., 131, 1461-1482, 2005b.

Prigent, C., Jiménez, C., and Catherinot, J.: Comparison of satellite microwave backscattering (ASCAT) and visible/near-infrared reflectances (PARASOL) for the estimation of aeolian aerodynamic roughness length in arid and semi-arid regions, Atmos. Meas. Tech., 5, 2703-2712, https://doi.org/10.5194/amt-5-27032012, 2012.

Reinfried, F., Tegen, I., Heinold, B., Hellmuth, O., Schepanski, K., Cubasch, U., Huebener, H., and Knippertz, P.: Simulations of convectively-driven density currents in the Atlas region using a regional model: Impacts on dust emission and sensitivity to horizontal resolution and convection schemes, J. Geophys. Res., 114, D08127, https://doi.org/10.1029/2008JD010844, 2009.

Ridley, D. A., Heald, C. L., and Prospero, J. M.: What controls the recent changes in African mineral dust aerosol across the Atlantic?, Atmos. Chem. Phys., 14, 5735-5747, https://doi.org/10.5194/acp-14-5735-2014, 2014.

Rodríguez, S., Cuevas, E., Prospero, J. M., Alastuey, A., Querol, X., López-Solano, J., García, M. I., and Alonso-Pérez, S.: Modulation of Saharan dust export by the North African dipole, Atmos. Chem. Phys., 15, 7471-7486, https://doi.org/10.5194/acp15-7471-2015, 2015.

Roehrig, R., Chauvin, F., and Lafore, J.-P.: 10-25-Day Intraseasonal Variability of Convection over the Sahel: A Role of the Saharan Heat Low and Midlatitudes, J. Climate, 24, 5863-5878, https://doi.org/10.1175/2011JCLI3960.1, 2011.

Ryder, C. L., McQuaid, J. B., Flamant, C., Rosenberg, P. D., Washington, R., Brindley, H. E., Highwood, E. J., Marsham, J. H., Parker, D. J., Todd, M. C., Banks, J. R., Brooke, J. K., Engelstaedter, S., Estelles, V., Formenti, P., Garcia-Carreras, L., Kocha, C., Marenco, F., Sodemann, H., Allen, C. J. T., Bourdon, A., Bart, M., Cavazos-Guerra, C., Chevaillier, S., Crosier, J., Darbyshire, E., Dean, A. R., Dorsey, J. R., Kent, J., O'Sullivan, D., Schepanski, K., Szpek, K., Trembath, J., and Woolley, A.: Advances in understanding mineral dust and boundary layer processes over the Sahara from Fennec aircraft observations, Atmos. Chem. Phys., 15, 8479-8520, https://doi.org/10.5194/acp15-8479-2015, 2015.

Schepanski, K. and Knippertz, P.: Soudano-Saharan depressions and their importance for precipitation and dust: a new perspective on a classical synoptic concept, Q. J. Roy. Meteor. Soc., 137, 1431-1445, https://doi.org/10.1002/qj.850, 2011.

Schepanski, K., Tegen, I., Laurent, B., Heinold, B., and Macke, A.: A new Saharan dust source activation frequency map derived from MSG-SEVIRI IR-channels, Geophys. Res. Letts., 34, L18803, https://doi.org/10.1029/2007GL030168, 2007.

Schepanski, K., Tegen, I., and Macke, A.: Saharan dust transport and deposition towards the tropical northern Atlantic, Atmos. Chem. Phys., 9, 1173-1189, https://doi.org/10.5194/acp-9-11732009, 2009a.

Schepanski, K., Tegen, I., Todd, M. C., Heinold, B., Bönisch, G., Laurent, B., and Macke, A.: Meteorological processes forcing Saharan dust emission inferred from MSG-SEVIRI observations of subdaily source activation and numerical models, J. Geophys. Res., 114, D10201, https://doi.org/10.1029/2008/JD010325, 2009 b.

Schepanski, K., Tegen, I., and Macke, A.: Comparison of satellite based observations of Saharan dust source areas, Remote Sens.
Environ., 123, 90-97, https://doi.org/10.1016/j.rse.2012.03.019, 2012.

Schepanski, K., Flamant, C., Chaboureau, J.-P., Kocha, C., Banks, J. R., Brindley, H. E., Lavaysse, C., Marnas, F., Pelon, J., and Tulet, P.: Characterization of dust emission from alluvial sources using aircraft observations and high-resolution modeling, J. Geophys. Res., 118, 7237-7259, https://doi.org/10.1002/jgrd.50538, 2013.

Schepanski, K., Knippertz, P., Fiedler, S., Timouk, F., and Demarty, J.: The sensitivity of nocturnal low-level jets and near-surface winds over the Sahel to model resolution, initial conditions and boundary-layer set-up, Q. J. Roy. Meteor. Soc., 141, 1442-1456, https://doi.org/10.1002/qj.2453, 2015a.

Schepanski, K., Klüser, L., Heinold, B., and Tegen, I.: Spatial and temporal correlation length as a measure for the stationarity of atmospheric dust aerosol distribution, Atmos. Environ., 122, 1021, https://doi.org/10.1016/j.atmosenv.2015.09.034, 2015b.

Schepanski, K., Mallet, M., Heinold, B., and Ulrich, M.: North African dust transport toward the western Mediterranean basin: atmospheric controls on dust source activation and transport pathways during June-July 2013, Atmos. Chem. Phys., 16, 14147-14168, https://doi.org/10.5194/acp-16-14147-2016, 2016.

Tao, W.-K., Chen, J.-P., Li, Z., Wang, C., and Zhang, C.: Impact of aerosols on convective clouds and precipitation, Rev. Geophys., 50, RG2001, https://doi.org/10.1029/2011RG000369, 2012.

Tegen, I. and Schepanski, K.: The Global Distribution of Mineral Dust, WMO/GEO Expert Meeting on an international Sand and Dust Strom Warning System, IOP Conf. Series: Earth and Environment Science, 7, 012001, https://doi.org/10.1088/17551307/7/1/012001, 2009.

Tegen, I., Harrison, S. P., Kohfeld, K., and Prentice, I. C.: Impact of vegetation and preferential source areas on global dust aerosol: Results from a model study, J. Geophys. Res., 107, 4576, https://doi.org/10.1029/2001JD000963, 2002.

Tegen, I., Schepanski, K., and Heinold, B.: Comparing two years of Saharan dust source activation obtained by regional modelling and satellite observations, Atmos. Chem. Phys., 13, 2381-2390, https://doi.org/10.5194/acp-13-2381-2013, 2013.

Thorncroft, C. D. and Blackburn, M.: Maintenance of the African easterly jet, Q. J. Roy. Meteor. Soc., 125, 763-938, https://doi.org/10.1002/qj.49712555502, 1999.

Vickery, K. J., Eckardt, F. D., and Bryant, R. G.: A subbasin scale dust plume source frequency inventory for southern Africa, 2005-2008, Geophys. Res. Lett., 40, 1-6, https://doi.org/10.1002/grl.50968, 2013.

Vizy, E. K. and Cook, K. H.: A mechanism for African monsoon breaks: Mediterranean cold air surges, J. Geophys. Res., 114, D01104, https://doi.org/10.1029/2008JD010654, 2009.

Wagner, R., Schepanski, K., Heinold, B., and Tegen, I.: Interannual variability in the Saharan dust source activation - towards understanding the difference between 2007 and 2008, J. Geophys. Res.-Atmos., 121, Issue 4538-4562 https://doi.org/10.1002/2015JD024302, 2016.

Webb, N. P. and Strong, C. L.: Soil erodibility dynamics and its representation for wind erosion and dust emission models, Aeolian Res., 3, 165-179, https://doi.org/10.1016/j.aeolia.2011.03.002, 2011.

Weinzierl, B., Ansmann, A., Prospero, J. M., Althausen, D., Benker, N., Chouza, F., Dollner, M., Farrell, D., Fomba, W., Freuden- 
thaler, V., Gasteiger, J., Groß, S., Haarig, M., Heinold, B., Kandler, K., Kristensen, T., Mayol-Bracero, O., Müller, T., Reitebuch, O., Sauer, D., Schäfler, A., Schepanski, K., Spanu, A., Tegen, I., Toledano, C., and Walser, A.: The Saharan Aerosol Long-range TRansport and Aerosol-Cloud-Interaction Experiment (SALTRACE): overview and selected highlights, B. Am. Meteorol. Soc., 98, 1-25, https://doi.org/10.1175/BAMS-D-15$00142.1,2017$.
Zhang, L., Gong, S., Padro, J., and Barrie, L.: A size-segregated particle dry deposition scheme for an atmospheric aerosol module, Atmos. Environ., 35, 549-560, 2001. 